\title{
CCAAT/Enhancer Binding Protein-Mediated Role of Thyroid Hormone in the Developmental Expression of the Kidney Androgen-Regulated Protein Gene in Proximal Convoluted Tubules
}

\author{
N. Teixidó, ${ }^{*}$ M. Soler, ${ }^{*}$ N. Rivera, J. Bernués, and A. Meseguer \\ Centre d'Investigacions en Bioquimica i Biologia Molecular (CIBBIM) (N.T., M.S., N.R., A.M.), Institut \\ de Recerca Vall d'Hebron, Pg. Vall d'Hebron 119-129, 08035 Barcelona, Spain; and Departament de \\ Biologia Molecular i Cellular (J.B.), Institut de Biologia Molecular de Barcelona, Consejo Superior de \\ Investigaciones Cientificas, Parc Científic de Barcelona, 08028 Barcelona, Spain
}

The kidney androgen-regulated protein (KAP) gene is exclusively expressed in proximal tubules of mouse kidney and in the uterus of pregnant females before they give birth. It displays an exquisite and differential regulation of expression by steroid and thyroid hormones (THs) in different proximal tubule segments. Whereas the pars recta (PR cells) responds to thyroid and sexual hormones, the pars convoluta (PCT cells) represents a truly androgen-dependent compartment because expression occurs only in the presence of androgens and functional androgen receptors. Nevertheless, different hypothyroidism models have indicated that TH might also contribute to the androgenic response in PCT cells. In the present study, we aimed to determine the molec- ular mechanisms that ultimately control KAP expression in these cells. Using several genetically deficient mouse models and different pharmacologic and hormonal treatments, we determined that thyroid and GH modulate CCAAT/enhancer binding protein $\alpha$ and $\beta$ levels that, in turn, control KAP expression in PCT cells in a developmentally dependent manner. We demonstrated that these factors bind to sites in the proximal KAP promoter, thereby collaborating with androgens for full KAP expression. Finally, we propose that TH and GH, acting through CCAAT/enhancer binding protein, may constitute a general regulatory mechanism of androgen-dependent genes in mouse kidney. (Molecular Endocrinology 20: 389-404, 2006)
$T^{+}$ HE KIDNEY ANDROGEN-regulated protein (KAP) was originally identified by in vitro translation of male mouse kidney mRNA (1). It constitutes the most abundant ( $4 \%$ of total polyadenylated mRNA) and specific gene expressed in proximal renal tubule cells, as shown by SAGE (serial analysis of gene expression) (2), SADE (a sage adaptation for down-sized extracts) (3), and expression profiling of active genes (4). Cell specificity and the complex regulatory mechanisms involved in KAP mRNA expression (5), together with KAP mRNA relative abundance, point to a significant role for its encoded protein. Analyses of both nucleotide and peptide sequences failed to reveal significant homology with other genes, expressed sequence tag or proteins, or with known structural or functional domains. The absence of known functional domains greatly reduced experimental

First Published Online September 8, 2005

${ }^{*}$ N.T. and M.S. contributed equally to this work.

Abbreviations: ARE, Androgen receptor response element; CAT, chloramphenicol acetyl transferase reporter gene; KAP, kidney androgen-regulated protein; LUC, luciferase; ODC, ornithine decarboxylase; PCT, pars convoluta; Pit-1, pituitary transcription factor-1; TH, thyroid hormone; PR, pars recta; PRL, prolactin.

Molecular Endocrinology is published monthly by The Endocrine Society (http://www.endo-society.org), the foremost professional society serving the endocrine community. approaches to elucidating KAP function, prompting us to perform a yeast two-hybrid assay that showed that KAP interacts with CsA binding protein CyPB, CsA administration reduces KAP steady-state levels in mouse kidney, and KAP overexpression reduces CsA toxicity in cultured proximal tubule cells. Thus, our data indicate a functional KAP, CyPB, and CsA-mediated toxicity relationship in kidney (6).

Our laboratory has been interested in understanding the regulation of KAP mRNA that displays a tissue- and cell-specific expression restricted to epithelial cells of proximal convoluted tubules in mouse kidney (7). This gene is subjected to strict and exquisite regulation by thyroid and sexual steroid hormones in different segments of proximal tubules. In vivo studies have shown that S3 cells (pars recta), which correspond to the outer stripe of the outer medulla, express the gene in the presence of thyroid hormone $\left(\mathrm{TH} / \mathrm{T}_{3}\right)(8)$, and are also sensitive to androgen and estrogen action (9). Females and castrated males express the gene exclusively in S3 cells (7). Segments S2 and S1 (pars convoluta), which correspond to the cortical part of the kidney, express the gene only in the presence of androgens and a functional androgen receptor (AR); therefore, females, castrated males or AR-deficient mice of the $\mathrm{Tfm} / \mathrm{Y}$ strain are negative for cortical expression of KAP mRNA (10). 
Accordingly, androgen replacement in castrated males or treatment of females with testosterone induces expression in the cortical segments of the tubule (7). We also observed that male mice genetically deficient for TH (hyt/hyt strain) exhibit lower cortical KAP mRNA expression than wild-type control males and that exogenous $\mathrm{T}_{3}$ injection prompts full expression recovery (8). Moreover, treatment of adult male control mice with potassium perchlorate $\left(\mathrm{KClO}_{4}\right)$, which reversibly competes for entry of iodine into the thyroid gland, resulting in severe pharmacological hypothyroidism, produces the same effect (11). These results, and the fact that simultaneous treatment of $\mathrm{KClO}_{4}$ and $\mathrm{TH}$ restored $\mathrm{KAP}$ expression in the cortex, strongly suggested the involvement of $\mathrm{TH}$ in the androgenic control of KAP mRNA expression in cortical tubule segments. Presence of $\mathrm{KClO}_{4}$ did not modify plasma testosterone levels or expression of the androgen receptor itself (11). More remarkably, animals born to mothers exposed to $\mathrm{KClO}_{4}$ during pregnancy and after delivery were unable to express KAP mRNA in any compartment of the kidney, including the cortical convoluted segments, even at postnatal d 90 (11). Because $T_{3}$ is unable to induce cortical expression in castrated males (8), we concluded that androgens are necessary but not sufficient to induce KAP expression in the cortex and that presence of $\mathrm{TH}$ is also required.

In the present work, we aimed to gain further insight into the molecular mechanisms that control TH involvement in the developmental sexual dimorphic pattern of KAP expression in mouse kidney by identifying the molecular elements that collaborate with androgens in the cortical expression of the KAP gene. To this end, in vivo and in vitro studies were conducted using the proximal tubule-derived cell line PKSV-PCT, originally developed in Dr. Vandewalle's laboratory $(12,13)$ that, together with the PKSV-PR, are alone in supporting androgen-dependent expression of kidney-specific genes in an isolated cell system (14). For years, the lack of an appropriate cell line has hampered detailed characterization of the molecular elements mediating androgen-responsive gene expression in the kidney. Our studies proved the hormone-specific regulation of the KAP gene promoter in these cultured mouse renal proximal tubule-derived cells (15), by demonstrating that these cell lines constitute an excellent and valuable ex vivo model for analyzing the mechanisms and further characterizing the molecular elements controlling the intricate and complex regulation of KAP gene in mouse kidney.

\section{RESULTS}

\section{Postnatal TH Requirement and GH Involvement in the Androgen-Dependent Expression of the KAP Gene in Kidney Cortex}

Previous work showed that male mice exposed to $\mathrm{KClO}_{4}$ from d 10 of gestation until being euthanized were not expressing the KAP gene, even at postnatal d 90, and related this effect to the absence of TH (11). To assess whether TH played a role during prenatal development, after birth or in both time periods, four different groups of animals were studied by in situ hybridization using specific antisense cRNA probes for KAP mRNA. Results showed that male and female control water-treated mice (group 1) and animals treated with $1 \% \mathrm{KClO}_{4}$ for the entire experiment (group 4) expressed the gene in the expected manner, as described $(7,11)$ (Fig. 1A). Results obtained in groups 2 and 3 showed that only animals treated with $1 \% \mathrm{KClO}_{4}$ during the gestational period (group 2) were able to express the gene like those in the control water-treated group.

Average size and weight of mice in each group showed significant differences for animals exposed to $1 \% \mathrm{KClO}_{4}$ (Fig. 1A, including table). For those under permanent treatment (group 4), weight and size were 2.5- and 1.5-fold lower, respectively, than in control animals (group 1), which suggests that an associated $\mathrm{GH}$ deficiency-related event to the strong hypothyroidism caused by the goitrogen treatment. As for KAP expression, effects on weight and size were clearer in postnatal treated mice (group 3) than in those exposed to treatment before birth (group 2). These results indicated that, at least in part, GH could be involved in KAP cortical expression. From previous work, we knew that when TH deficiency occurs in the absence of a dwarf-associated phenotype, i.e. in the hyt/hyt mouse model, cortical expression is diminished but not abolished (8); therefore, we hypothesized that, the combined absence of $\mathrm{GH}$ and $\mathrm{TH}$ would likely result in lack of KAP expression. To demonstrate this hypothesis, we used two genetically deficient mouse models, $\mathrm{GH}$ and prolactin (PRL)-deficient little mice and pituitary transcription factor-1 (Pit-1)-deficient $\mathrm{C} 3 \mathrm{H} / \mathrm{HeJ}$ dwarf mice from The Jackson Laboratory (Bar Harbor, ME). The specific pituitary transcription factor Pit-1 deficiency led to absence of GH, PRL, and $\mathrm{TSH}$ in the $\mathrm{C} 3 \mathrm{H} / \mathrm{HeJ}$ mice, resulting in a combined hypothyroid and dwarf phenotype. Results from this experiment showed that deficiency of $\mathrm{GH}$ and PRL does not compromise androgen-dependent cortical KAP expression (little) as does combined absence of GH, PRL, and TSH (Jackson dwarf) (Fig. 1B).

Goitrogen-treated male mice were injected with $\mathrm{T}_{3}, \mathrm{GH}$, or both at the same time, from postnatal $d$ $7-21$, to further verify the involvement of these hormones in the pharmacological model and to demonstrate that the results obtained were not indirectly related to putative nephrotoxic effects of $\mathrm{KClO}_{4}$ in the kidney. In situ hybridization experiments showed that $\mathrm{T}_{3}$ administration restored KAP expression in both kidney compartments (outer medulla and cortex). This effect was enhanced by coinjection of $\mathrm{GH}$, although GH administration alone produced no effect (Fig. 1C). 
A
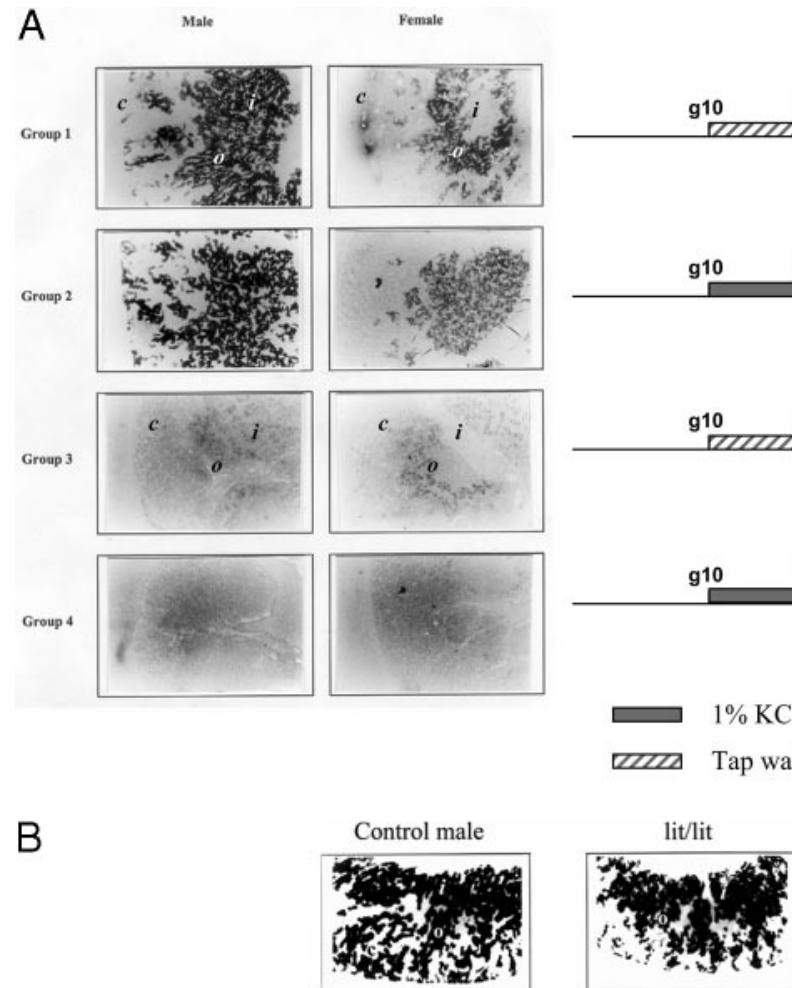

Perclorate Potassium $1 \%$ male
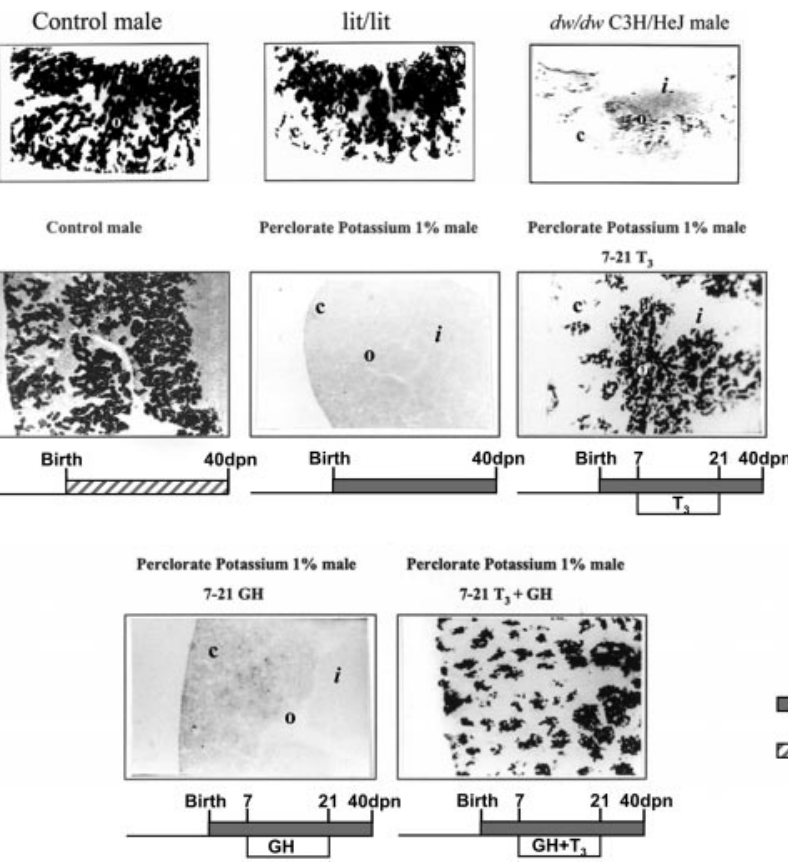

$$
7-21 \mathrm{~T}_{3}+\mathrm{GH}
$$

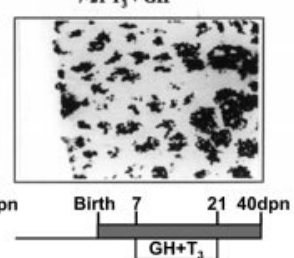

\section{$1 \% \mathrm{KClO}$ \\ Tap water}

$* * p=0.001$
$* p=0.05$

\begin{tabular}{|c|c|c|c|}
\hline & Sex & Weight ( $g$ ) & Size $(\mathrm{cm})$ \\
\hline Group 1 & $\begin{array}{l}\text { Male } \\
\text { Female }\end{array}$ & $\begin{array}{l}19.7 \pm 1.9^{* * *} \\
18.9 \pm 1.5^{* *}\end{array}$ & $\begin{array}{l}5.6 \pm 0.3 \\
5.5 \pm 0.3\end{array}$ \\
\hline Group 2 & $\begin{array}{l}\text { Male } \\
\text { Female }\end{array}$ & $\begin{array}{l}15.1 \pm 3.6^{*} \\
13.2 \pm 2.7^{*}\end{array}$ & $\begin{array}{l}4.8 \pm 0.4 \\
4.6 \pm 0.3\end{array}$ \\
\hline Group 3 & $\begin{array}{l}\text { Male } \\
\text { Female }\end{array}$ & $\begin{array}{l}10.3 \pm 1.7^{*} \\
11.5 \pm 2.5\end{array}$ & $\begin{array}{l}4.3 \pm 0.3 \\
4.4 \pm 0.4\end{array}$ \\
\hline Group 4 & $\begin{array}{l}\text { Male } \\
\text { Female }\end{array}$ & $\begin{array}{l}7.8 \pm 1.8^{*} \\
8.0 \pm 1.9^{*}\end{array}$ & $\begin{array}{l}3.6 \pm 0.3 \\
3.6 \pm 0.4\end{array}$ \\
\hline
\end{tabular}

Fig. 1. TH and GH Influence KAP mRNA Expression in Kidney Cortex

A, Effects of pre/postnatal TH deprivation on KAP gene expression. Frozen male and female kidney sections from animals exposed permanently to regular tap water (Group 1), those treated with $\mathrm{KClO}_{4} 1 \%$ in drinking water from d 10 of gestation until birth (Group 2), those with $\mathrm{KClO}_{4} 1 \%$ from birth until euthanized at postnatal d 40 (Group 3) or those exposed to $\mathrm{KCIO}_{4} 1 \%$ from d 10 of gestation until euthanized at postnatal d 40 (Group 4) were hybridized with strand-specific ${ }^{35}$ S-KAP3 antisense cRNA. The magnification chosen for these images $(\times 40)$ permitted visualization of the three major compartments of the kidney $(c$, cortex; 0 , outer medulla; i, inner medulla). At right, the table displays average weight and size of the animals belonging to each group and classified by sex. B, KAP gene expression in lit/lit and Jackson $d w / d w$ mice. Frozen kidney sections from control (left panel), homozygous lit/lit (middle panel), and Jackson $d w / d w$ (right panel) male mice were hybridized with strand-specific ${ }^{35} \mathrm{~S}-\mathrm{KAP}$ (KAP3) cRNA as previously described. The left panel corresponds to a kidney section from a normal male of the C57BL/6 Lit/+ genetic background. Hybridization of frozen sections from a normal male of the $\mathrm{C}^{3} \mathrm{H} / \mathrm{HeJ} d w^{j} /+$ strain yielded similar results (data not shown). C, KAP gene expression in male mice exposed to $1 \% \mathrm{KClO}_{4}$ and treated with $\mathrm{T}_{3}$ - and/or GH. Frozen kidney sections from C/57BL6 untreated control males (left upper panel), potassium perchlorate 1\%-treated males from birth until euthanized at postnatal d 40 (middle upper panel), or similar mice treated with TH (right upper panel), GH (left lower panel), and TH plus GH (right lower panel) from postnatal d 7-21 were hybridized with strand-specific ${ }^{35}$ S-KAP (KAP3) cRNA as previously described. 


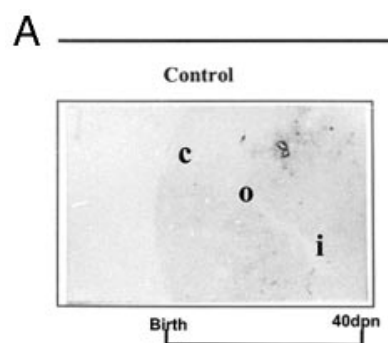

Potassium Perclorate $1 \%$ treated males
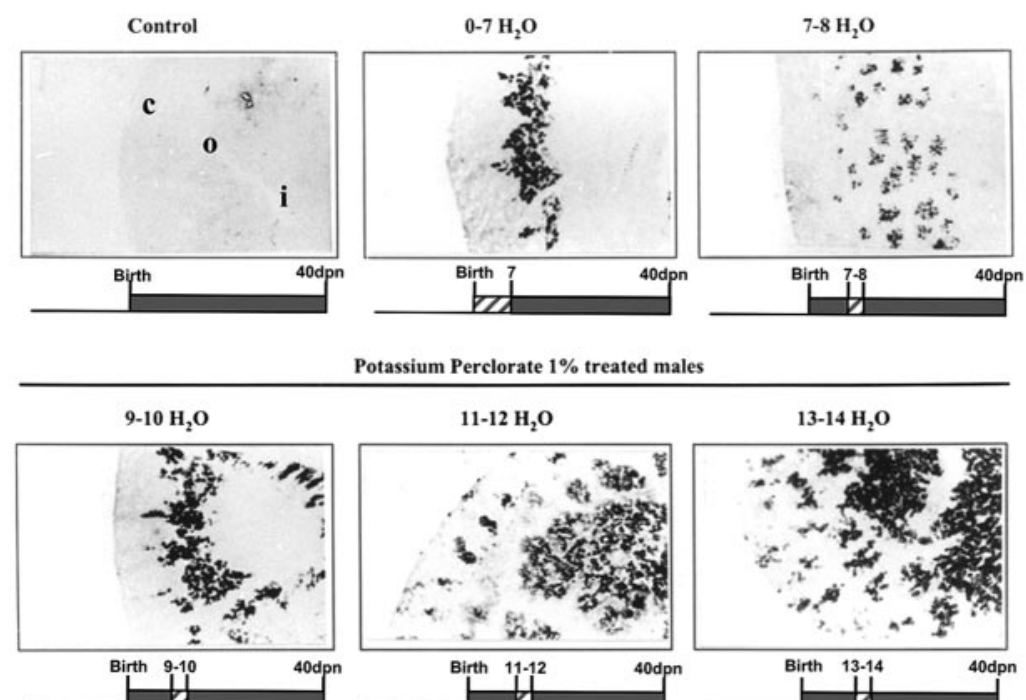

Potassium Perclorate $1 \%$ treated males

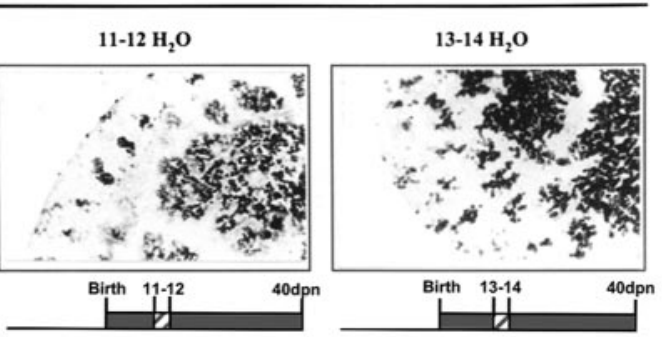

Non-treated control male

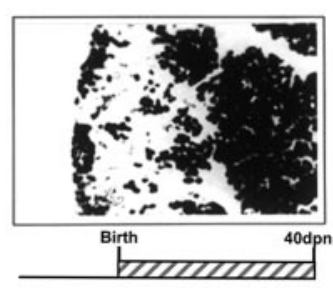

Potassium Perclorate $1 \%$ treated males

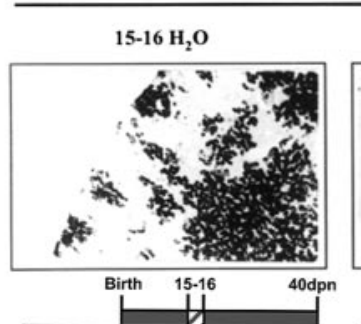

$16-26 \mathrm{H}_{2} \mathrm{O}$
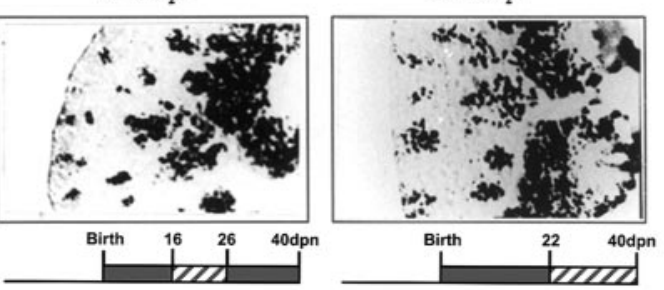

Potassium Perclorate 1\%

0-14 $\mathrm{H}_{2} \mathrm{O}$
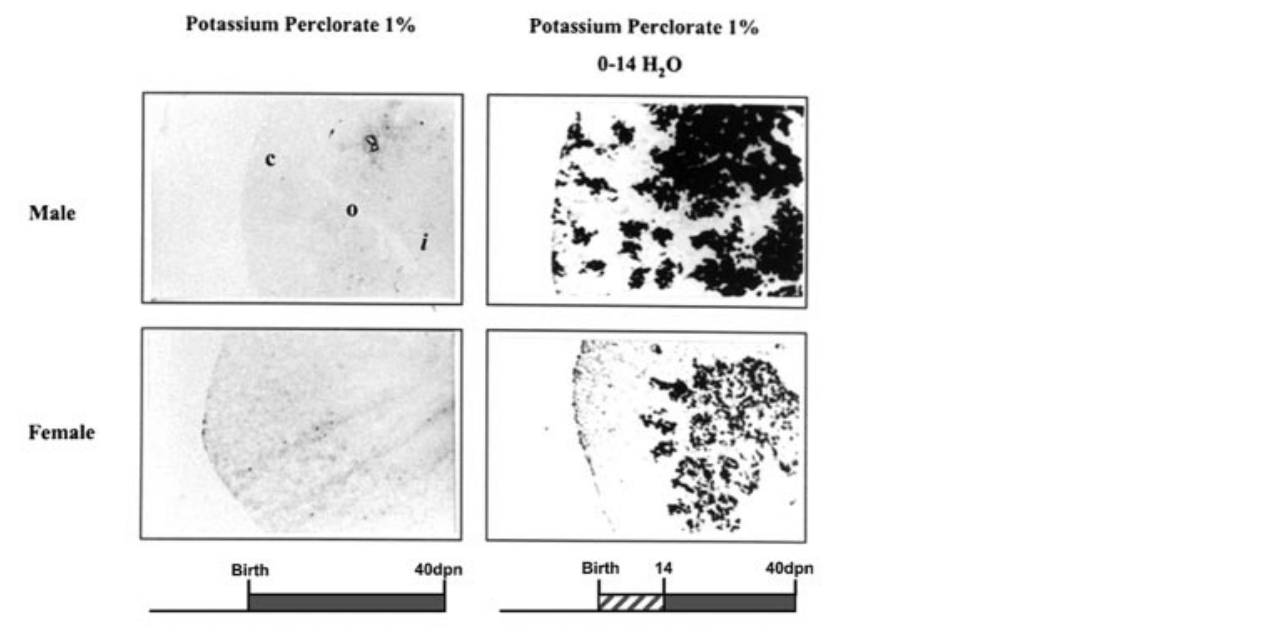

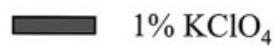

एس] Tap water

B

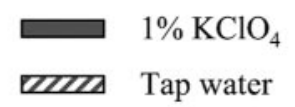

Fig. 2. Punctual Presence of TH Triggers KAP Expression in Cortex

A, Restoration of TH synthesis on goitrogen removal at different postnatal time points permits recovery of KAP gene expression in potassium perchlorate-treated male mice. Frozen kidney sections from C57BL/6 potassium perchlorate-treated males from birth until euthanized at postnatal d 40 (control; upper left panel) were hybridized with strand-specific ${ }^{35}$ S-KAP (KAP3) cRNA, as previously described and compared with similar animals exposed to tap water from indicated time points (see figure) and further exposed to perchlorate in drinking water until euthanized. In situ hybridization of nontreated control males from birth until 


\section{Punctual Presence of $T_{3}$ Is Sufficient to Trigger KAP Expression}

We next aimed to investigate at what time points in postnatal development $\mathrm{TH}$ was required to trigger KAP expression. To avoid stressing the animals with daily $T_{3}$ injections, a different strategy was used based on replacing $1 \% \mathrm{KClO}_{4}$ containing water by normal tap water during the time points studied. Before proceeding with this novel approach, we tested whether this treatment had equivalent effects to $\mathrm{T}_{3}$ injection in animals exposed to $1 \% \mathrm{KClO}_{4}$ during the same period of time. Results on KAP expression when mice were euthanized (postnatal d 40) confirmed that both procedures had similar effects (data not shown); concomitantly, weights of animals under both treatments were practically identical: $13.31 \mathrm{~g} \pm 0.1$ for those exposed to $T_{3}$ from postnatal $\mathrm{d} 7-21$ and $13.98 \mathrm{~g} \pm 0.1$ for those exposed to tap water from postnatal d 7-21. Control males had a weight of $19.7 \mathrm{~g} \pm 0.1 \mathrm{vs} .8 \mathrm{~g} \pm 0.1$ of those permanently exposed to $1 \% \mathrm{KClO}_{4}$.

Once the procedure had been confirmed as effective, hypothyroid animals (potassium perchloratetreated males) were exposed to regular tap water for different time periods (see Fig. 2A) and KAP mRNA expression was compared with that of age- and sex-matched animals exposed to tap water (nontreated control male) or potassium perchlorate (control) at $40 \mathrm{~d}$ postnatally. Results showed in Fig. 2A, indicated that the presence of $T_{3}$ around postnatal $d$ 12 and beyond facilitated KAP expression and that $48 \mathrm{~h}$ exposure to tap water seemed sufficient to produce this effect. Female mice treated with tap water from birth to d 14 were negative for KAP expression in cortex at d 40 (Fig. 2B), whereas males treated in the same manner exhibited KAP expression in this compartment. These results indicated that only in males was the presence of TH after postnatal d 12 required to trigger KAP expression in cortex and that once this had occurred, the presence of $\mathrm{TH}$ was no longer required.

\section{Expression of CCAAT/Enhancer Binding Protein (c/EBP) $\alpha$ and $\beta$ Genes under Different Hormonal Conditions and Correlation with KAP Expression in Mouse Kidney}

Because TH was not able to induce KAP mRNA in the cortex of castrated males (8), and because KAP proximal promoter does not contain canonical $\mathrm{TH}$ receptor binding sites, we proposed an indirect action of $\mathrm{TH}$ in
KAP expression. Among different possibilities, we first explored whether other transcription factors under TH control might be collaborating with androgens on KAP regulation. Inspection of the KAP proximal promoter indicated different putative transcription factor binding sites, including several for the c/EBP family members, at positions $-457,-429,-110$, and -66 , from the transcription initiation site (16). Because it had been described that $\mathrm{TH}$ was regulating $\mathrm{c} / \mathrm{EBP} \alpha$ and $\beta$ gene expression (17) and also because of the significance of these transcription factors in development, we investigated their expression levels in mouse kidney, under different hormonal conditions and correlated them with those of KAP mRNA.

c/EBP $\alpha$ and $\beta$ levels in kidneys of male mice exposed to $1 \% \mathrm{KClO}_{4}$ or castration were assessed by Western blot assays. Results clearly showed c/EBP $\alpha$ and $\beta$ expression to be residual in $1 \% \mathrm{KClO}_{4}$-treated mice and levels of both factors to be reduced in castrated males (Fig. 3A). Semiquantitative RT-PCR in the same kidney samples revealed an almost undetectable expression of KAP mRNA in the presence of 1\% $\mathrm{KClO}_{4}$ and an obvious decrease in castrated males (Fig. 3B), in agreement with previous in situ hybridization results. Changes in KAP mRNA expression correlated well with $\mathrm{c} / \mathrm{EBP} \alpha$ and $\mathrm{b}$ protein levels, thereby indicating a possible functional relationship. To further test this hypothesis, $\mathrm{c} / \mathrm{EBP} \alpha$ and $\beta$ protein levels were determined in kidneys of potassium perchloratetreated males (controls), animals additionally given $\mathrm{TH}$ from postnatal d 7-21 (7-21 d $\mathrm{T}_{3}$ ) and controls (nontreated control males). Western blot assays indicated that $\mathrm{c} / \mathrm{EBP} \alpha$ and $\beta$ were recovered in the $\mathrm{TH}$-treated males (Fig. $3 \mathrm{C}$ ) and that KAP mRNA was also expressed under these conditions (Fig. 3D). In summary, the clear correlation observed among hormonal status of the animals, c/EBP $\alpha$ and $\beta$ levels and KAP mRNA expression strongly suggests involvement of c/EBPs in KAP gene expression.

\section{Effects of c/EBP $\alpha$ and $\beta$ on KAP Promoter Transcription in РСТЗ Cells}

PCT3 cells, derived from the parental PKSV-PCT, have already shown their ability to support androgenic regulation of reporter gene constructs containing the kidney-specific KAP promoter in transient transfection assays (15). To further investigate the concept that TH-dependent expression of KAP mRNA in cortical segments of proximal tubules might relate to the presence of c/EBP $\alpha$ and $\beta$, transient transfection assays using the -638 KAP proximal promoter fragment

\footnotetext{
euthanized has also been included (rightmost panel) (c, cortex; o, outer medulla; i, inner medulla). B, Differential KAP cortical expression in potassium perchlorate-treated male and female mice, after postnatal d 14. Frozen kidney sections from C57BL/6 potassium perchlorate-treated male and female mice from birth until euthanized at postnatal d 40 (left upper and lower panels, respectively) were hybridized with strand-specific ${ }^{35} \mathrm{~S}-\mathrm{KAP} 3 \mathrm{cRNA}$ probes, as previously described, and compared with similar animals exposed to tap water from birth until postnatal $\mathrm{d} 14$, and to potassium perchlorate from d 15 until euthanized at $\mathrm{d} 40$ (right upper and lower panels).
} 
A

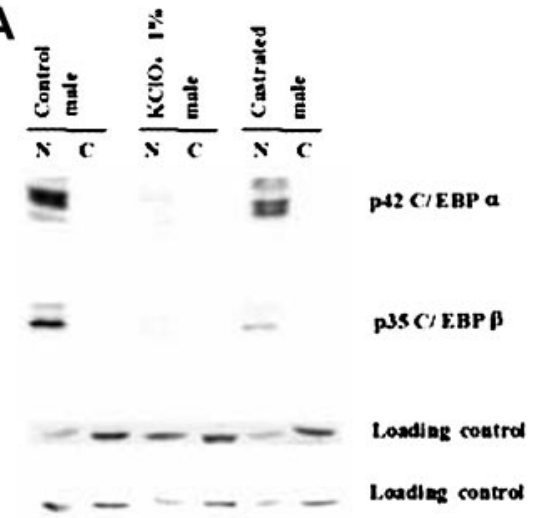

C

Potassimm Perclorate treated males $1 \%$

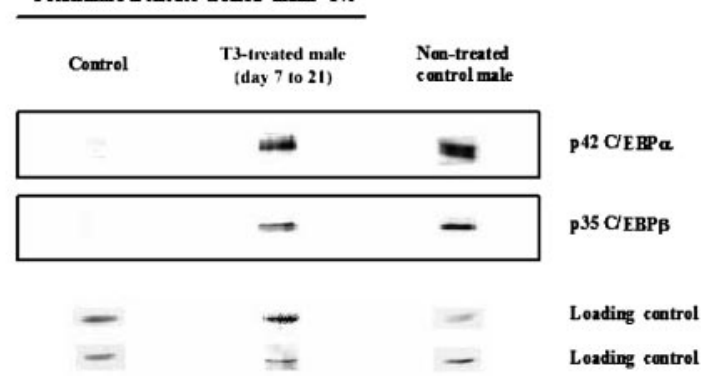

B
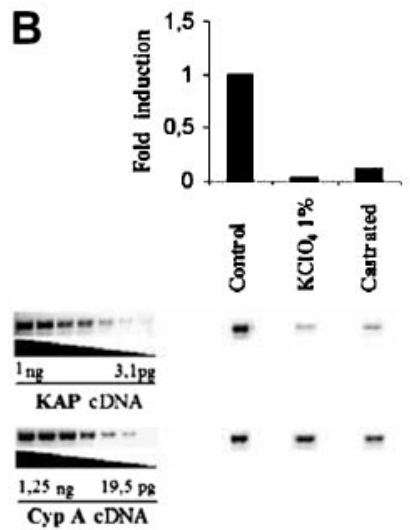

D

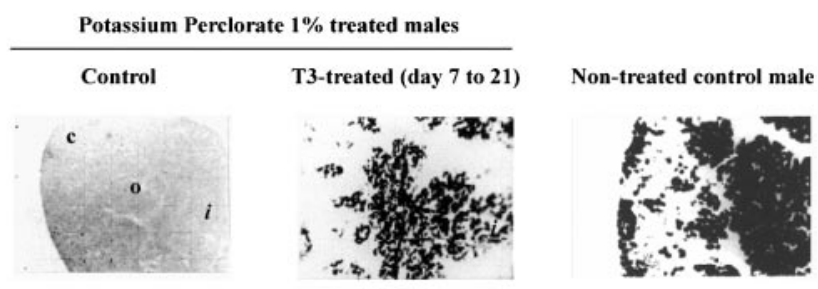

Fig. 3. $c / E B P$ Levels Correlate with KAP mRNA Expression in Cortex

$A$, Effects of postnatal hypothyroidism and castration on $\mathrm{c} / \mathrm{EBP} \alpha$ and $\mathrm{c} / \mathrm{EBP} \beta$ protein levels in mouse kidney. Western blot assays were performed with nuclear $(\mathrm{N})$ and cytosolic $(\mathrm{C})$ extracts from kidneys of untreated control C57BL/6 male mice (control male), mice treated with $1 \% \mathrm{KClO}_{4}$ in drinking water from birth until euthanized at postnatal d $40\left(\mathrm{KClO}_{4} 1 \%\right.$ male) and castrated mice (castrated male). Antibodies against c/EBP $\alpha$ (p42) and c/EBP $\beta$ (p35/p38) were used as described in Material and Methods. Specificity of the signals obtained with these antibodies was previously tested by incubation of each antibody with a 5 -fold excess of their specific peptide (sc-61 P for c/EBP $\alpha$ and sc-150 P for $\beta$, both from Santa Cruz Biotechnologies) (not shown). Blots presented in the figure were performed with antibodies blocked with nonspecific peptides (M-20 for mouse gp130). Protein loading was assessed by gel staining with Coomassie brilliant blue and indicated on the figure as loading control for c/EBP $\alpha$ and $\beta$ blots, respectively. B, Endogenous KAP mRNA expression levels in postnatal hypothyroid and castrated male mice. Endogenous KAP mRNA levels were measured by semiquantitative RT-PCR technique (see Materials and Methods for details) in extracts obtained from the contralateral kidney of the same animals used for c/EBP protein detection (see text of Fig. 3A). The KAP/Cyp A ratio is expressed as fold increase over basal level, as previously described (15). C, c/EBP $\alpha$ and $\beta$ protein levels in hypothyroid male mice treated postnatally with $\mathrm{TH}$. The experimental procedure was the same as described in Fig. $3 \mathrm{~A}$. c/EBP $\alpha$ and $\beta$ levels were determined in kidneys of $1 \%$ potassium perchlorate-treated males from birth until euthanized ( $40 \mathrm{~d}$ postnatal) (control), in similar animals treated from postnatal d 7-21 with daily doses of TH $(1.2 \mu \mathrm{g})\left(7-21 \mathrm{~T}_{3}\right.$-treated males) and both were compared with naive male mice of the same age (nontreated control male). D, KAP mRNA levels on hypothyroid male mice treated postnatally with TH. In situ hybridization in contralateral kidneys of the same animals used for c/EBP protein detection (see text of panel C). Technical procedures were the same as those described in Fig. 1A. c, Cortex; o, outer medulla; i, inner medula.

fused to chloramphenicol acetyl transferase reporter gene (CAT) were performed (Fig. 4A). Experiments were carried out in PCT3 cells under different hormonal treatments and in the presence or not of cotransfected expression vectors for $\mathrm{c} / \mathrm{EBP} \alpha$ and $\beta$ cDNAs.

Results indicated that $\mathrm{c} / \mathrm{EBP} \alpha$ or $\mathrm{c} / \mathrm{EBP} \beta$ alone (lanes 7 and 8, respectively) exhibited the same transactivation capacity as DHT in the presence of a transfected functional androgen receptor (lane 3) on the -638 KAP promoter ( $\sim$-fold) (Fig. 4A). When androgens and androgen receptor were included together with $\mathrm{c} / \mathrm{EBP} \alpha, \beta$ or both, activity was around 5- to 6-fold higher (lanes 4-6, respectively). These results indicated a role for $\mathrm{c} / \mathrm{EBP} \alpha$ and $\beta$ as well as an additive effect of androgens and these transcription factors on KAP gene transactivation.

\section{Site-Directed Mutagenesis of Putative c/EBP Binding Sites in the KAP Promoter}

Site-directed mutagenesis was performed on the $224 \mathrm{~K}$ and $638 \mathrm{~K}$ KAP constructs fused to the luciferase (LUC) reporter gene to further investigate whether the putative c/EBP binding sites identified in the KAP promoter were functionally relevant. The K224 construct contains two putative sites, from -66 to -56 and from -110 to -101 from the transcriptional initiation site, 


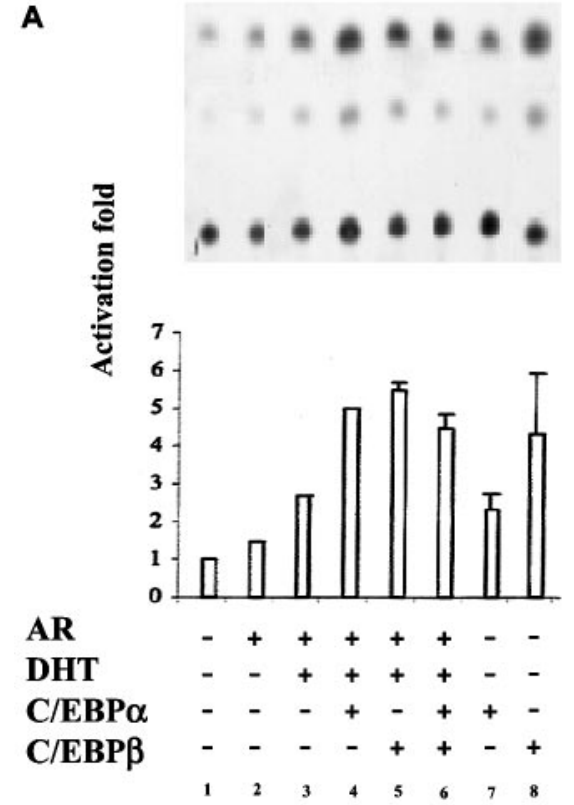

B

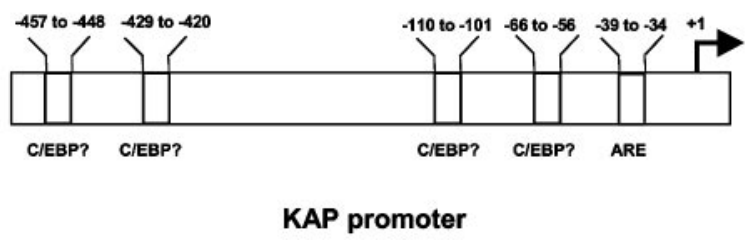

Fig. 4. c/EBP Affects KAP Promoter Transactivation in PCT Cells

A, Effects of androgens and $\mathrm{c} / \mathrm{EBP} \alpha$ and $\beta$ on the transcriptional activity of the K638 promoter construct in PCT3 cells. Cultured mouse PCT 3 cells were transfected with $2 \mu \mathrm{g}$ of the $\mathrm{K} 638$ construct, in the presence of $0.5 \mu \mathrm{g}$ of cotransfected human androgen receptor (AR) expression vector $\mathrm{pS}$ VARO (lanes 2-6) and treated for $48 \mathrm{~h}$ with vehicle (lanes 1, 2, 7, and 8) or with $10^{-6} \mathrm{M} \mathrm{DHT}$ (lanes 3-6) in steroid-free medium. A total of $0.5 \mu \mathrm{g}$ of pMSV-c/EBP $\alpha$ and PMSV-c/ EBP $\beta$ expression vectors, which contain the entire open reading frame of rat $\mathrm{c} / \mathrm{EBP} \alpha$ and mouse $\mathrm{c} / \mathrm{EBP} \beta$ (p35 LAP), was also cotransfected to the same cells, either alone (lanes 7 and 8) or in different combinations that include cotransfection of AR and presence of DHT (lanes 4-6). Autoradiograms of CAT assays measured in homogenates of transfected cells are shown in the upper part of the figure. CAT activities were adjusted according to the $\beta$-galactosidase activity produced by $2 \mu \mathrm{g}$ of transfected $\mathrm{pCH} 110$ plasmid. Bars indicate the mean ( $\pm \mathrm{SE}$ ) of fold induction of reporter activities over control unstimulated, nonreceptor or c/EBPs-transfected cells $(=1)$ for a minimum of three independent experiments. B, Outline of the proximal KAP promoter. ARE and the four putative $\mathrm{C} / \mathrm{BBP}$ binding sequences positions on proximal KAP promoter are shown.

which were individually deleted and assayed by transient transfection in PCT3 cells. The same was done within the K638 construct where sites -66 to -56 , -110 to $-101,-429$ to -420 and -457 to -448 were individually deleted and tested (henceforth referred to as: $-66,-110,-429$ and -457 ) (Fig. 5A). Although results from these experiments indicated no significance for any of the individually mutated sites (Fig. $5 B)$, a second set of experiments revealed that the simultaneous mutation of the -457 and -429 sites in the K638 construct produced a strong decrease in their transcriptional activity, which dropped approximately 35- to 40-fold, compared with that of the K638 control construct (Fig. 5C). c/EBP $\alpha$ or $\beta$ cotransfection did not affect the transcriptional capacity of the K638 double-mutated construct (Fig. 5C). Triple mutated constructs, including the other two sites at positions -110 or -66 , did not produce additional effects to those obtained with the double mutated construct (Fig. 5C).

From the in vivo experiments, we concluded that $\mathrm{TH}$ controls androgen-dependent cortical KAP gene expression through modulation of factors that might collaborate with androgens in the presence of a functional AR. To determine whether the sites at positions -457 and -429 were affected by the absence of steroid hormones in the culture media and/or the absence of the androgen receptor response element (ARE), previously defined at position -39 on the KAP promoter (15), transient transfection assays in complete or steroid hormone-free media were performed. Results (Fig. 5D, upper left panel) showed that mutation of the ARE further decreased the relative activity of the -457 and -429 mut $\mathrm{K} 638$ construct that went from 40 -fold to 100 - to 150 -fold. In the absence of steroid hormones (Fig. 5D, right side of the upper panel), the effects were comparable to mutation of the ARE; no significant differences were observed between the K638( $\Delta 457-448, \Delta 429-420)$ or the $\mathrm{K} 638(\Delta 457-448, \Delta 429-420, \Delta 39-35)$ construct, indicating that androgens, acting through this androgen receptor binding site, together with factors binding to the -457 and -429 sites collaborated on the transcriptional activity of the KAP promoter.

The transcriptional activity of the pGL3 basic vector was influenced neither by the presence of transfected c/EBP expression vectors nor by the culture conditions used (Fig. 5D, lower pane/s), which proved that the effects observed were KAP promoter dependent.

\section{C/EBP $\alpha$ and $\beta$ Bind to the -457 Box}

All evidence found in the above-described experiments, both in kidney and in PCT3 cells, pointed to $\mathrm{c} / \mathrm{EBP} \alpha$ and $\beta$ as the putative transcription factors able to control KAP gene expression in the presence of androgens.

To reinforce this concept, gel retardation assays were performed with oligonucleotides corresponding to the 457 and 429 boxes, in the presence of nuclear extracts obtained from kidneys or PCT 3 cells. Results (Fig. 6A) showed that there were nuclear factors in PCT3 cells able to bind to these two boxes and, also, 
A

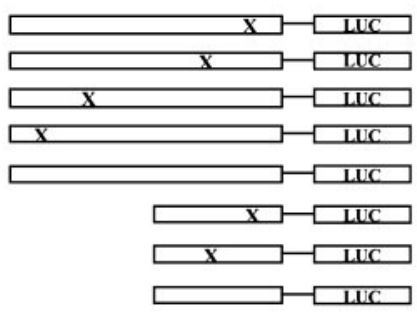

K638 ( $\Delta 66-57)$

K638 ( $(\Delta 110-101)$

K638 ( $(429-420)$

K638 ( $\Delta 457-448)$

K638

K224 ( $(\Delta 66-57)$

K224 ( $(110-101)$

K224
B

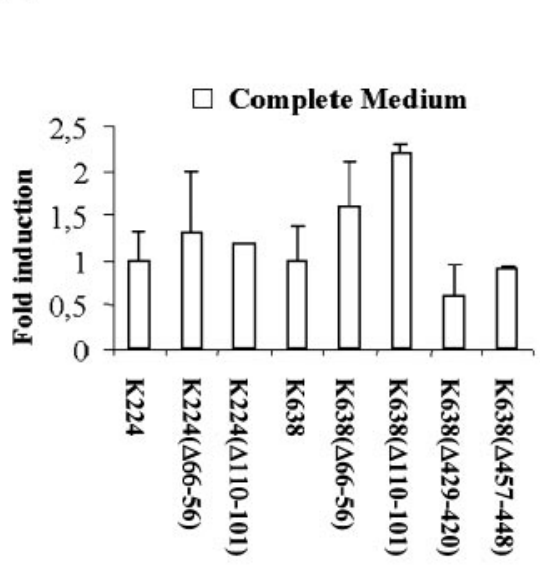

C
Complete Medium

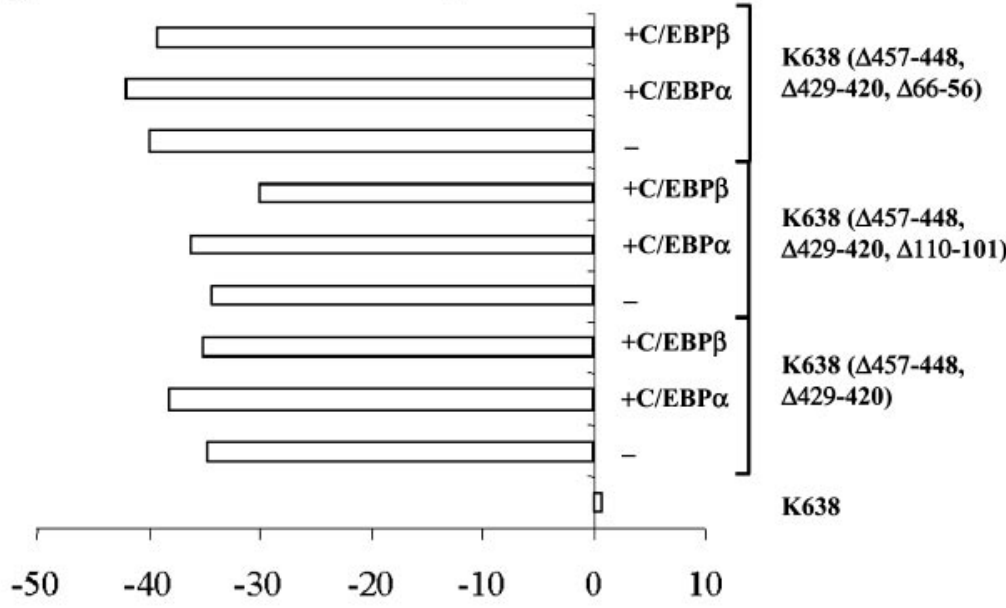

Fold induction

D Complete Medium

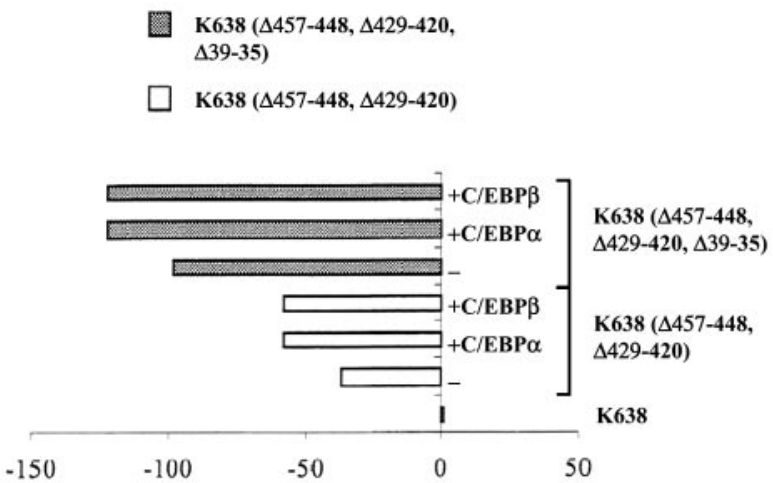

Fold induction

Complete Medium

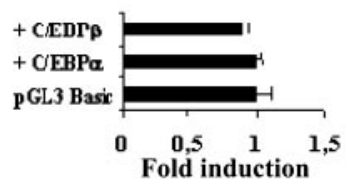

Steroid-free Medium

$\mathrm{K} 638(\Delta 457-448, \Delta 429-420$, $\Delta 39-35)$

$\square \mathrm{K} 638(\Delta 457-448, \Delta 429-420)$

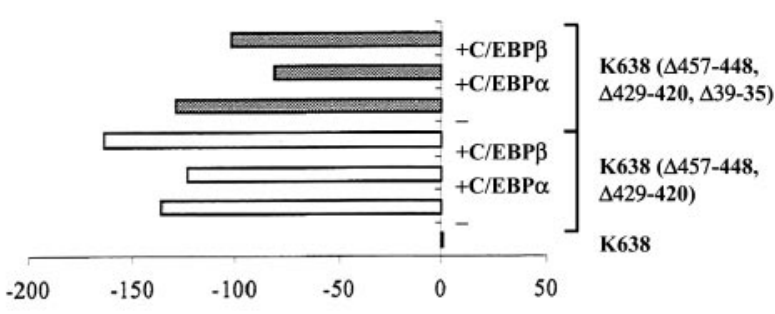

Fold induction

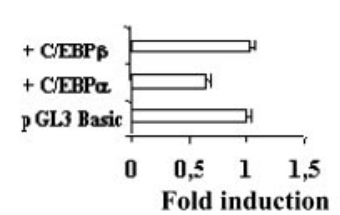

Fig. 5. Functional Analysis of Putative c/EBP Mutated Sites on the KAP Promoter

A, Set of the different mutated versions of the LUC K638 and K224 KAP promoter reporter constructs. Nucleotides deleted from native sequences on the K224 and K638 promoter constructs were the following: positions 66-56 [K638/224 ( $\triangle 66-56)$ ]:

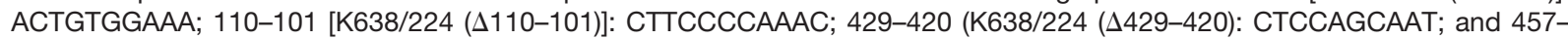
448 [K638 ( $\Delta 457-448)$ ]: CTTTTGCAAT. B, Functional assays of single deletion of the putative c/EBP binding sites on the KAP promoter. Functional activities of $1 \mu \mathrm{g} \mathrm{K} 224$ or K638 (wild type) were tested on PCT3 cells and compared with $1 \mu \mathrm{g}$ of each mutated construct. LUC activities were adjusted according to the Renilla LUC activity produced by $20 \mathrm{ng}$ of transfected pRL-TK 
to a consensus wild-type (WT) c/EBP box, but not to a mutant one (MUT). To determine the specificity of these retarded band, competition experiments including 30-fold excess of cold 457, 429, c/EBP WT, and c/EBP MUT oligonucleotides were performed. Results (Fig. 6B) showed that the retarded band on 457 box is competed out by cold WT c/EBP or by the same 457 sequence, but not by the c/EBP MUT. Because box 429 was only competed by its own sequence, our results suggested that the factor bound to the 457 sequence, but not that one bound to the 429 sequence, may belong to the c/EBP family. Next, we aimed to identify the nature of this factor by performing supershift assays with antibodies against c/EBP $\alpha$ and $\beta$. As expected, the retarded band for the 429 box was unaffected by the presence of the antibodies. Anti-c/EBP $\beta$, but not anti-c/EBP $\alpha$, produced a supershift of the 457 and c/EBP WT boxes (Fig. 6C). The lack of $\mathrm{c} / \mathrm{EBP} \alpha$ supershift could not be attributed to absence of this isoform because its presence in the PCT3 nuclear extract was determined by Western blot analysis (not shown). Similar experiments performed with male mouse kidney nuclear extracts produced retarded bands for the 457 box that were competed by c/EBPWT but not by c/EBPMUT (Fig. 6D). When using these extracts, supershifts occurred with both anti-c/ $\operatorname{EBP} \beta$ and anti-c/EBP $\alpha$ antibodies (Fig. 6E) indicating that, contrary to what occurs in PCT3 cells, both $\mathrm{c} / \mathrm{EBP}$ factors are able to bind to the 457 box in mouse kidney extracts. Note that kidney extracts contain c/EBPs from all their different cell types. Whether this difference in binding ability to the 457 box is due to a different cellular origin of the active $\mathrm{c} / \mathrm{EBP} \alpha$ in whole kidney (i.e. not necessarily coming from cortex cells) or reflects an abnormal behavior of $\mathrm{c} / \mathrm{EBP} \alpha$ of the PCT cells is not known. The nature of the factor that binds to the 429 box and the mechanisms that operate to make c/EBP $\alpha$ incompetent to bind to the 457 box in PCT3 cells remain to be determined.

\section{DISCUSSION}

Although earlier in situ hybridization assays in mouse kidney had clearly demonstrated that the presence of androgens and functional androgen receptors were instrumental and apparently sufficient for KAP gene expression in cortical S1 and S2 segments of proximal tubules (10), later studies revealed the important contribution of $\mathrm{TH}$ to achieve a full androgen-dependent cortical response in males (8).

Although $\mathrm{TH}$ involvement was established, striking differences arose in KAP mRNA expression levels between congenital hypothyroid hyt/hyt adult males (8) and adult mice exposed to potassium perchlorate from d 10 of gestation until euthanized at postnatal $d$ 90 (11). The hyt mice present primary hypothyroidism related to the hyporesponsiveness of the thyroid gland to $\mathrm{TSH}$, which results in very low $\mathrm{TH}$ serum levels and abnormally high TSH levels (18). Perchlorate inhibits the transport of iodine into the thyroid in a competitive and reversible manner, which results in a decrease of $\mathrm{TH}$ production $\left(\mathrm{T}_{4}\right.$ and $\left.\mathrm{T}_{3}\right)$ and an increase in $\mathrm{TSH}$ production (19). In the past, we had determined $T_{4}$ and $\mathrm{T}_{3}$ concentrations in kidneys of hypothyroid mice (8, 11). Adult animals treated for 1 wk with $\mathrm{KClO}_{4}$ gave values that ranged from $0.258-0.524 \mathrm{ng}$ of $\mathrm{T}_{3}$ and from $0.734-1.119 \mathrm{ng}$ of $\mathrm{T}_{4} / \mathrm{g}$ tissue. Although very difficult because of their small size, congenital perchloratetreated mice were also analyzed and values of $\mathrm{T}_{3}$ and $\mathrm{T}_{4}$ in kidney tissues ranged from $0.306-0.742 \mathrm{ng}$ of $\mathrm{T}_{3}$ and from $0.643-2.260 \mathrm{ng}$ of $\mathrm{T}_{4} / \mathrm{g}$ of tissue. Animals of the hyt/hyt strain had values ranging from $0.548-0.974$ ng of $\mathrm{T}_{3}$ and from $0.857-2.85 \mathrm{ng}$ of $\mathrm{T}_{4} / \mathrm{g}$ of tissue. We concluded that $\mathrm{KClO}_{4}$ treatment was effective to render the animals hypothyroid, with $\mathrm{TH}$ values being even lower than those in the hyt/hyt mice. Untreated control mice ranged from 1.3-2.4 or higher ng of $\mathrm{T}_{3} / \mathrm{g}$ of tissue.

in the same sample. Fold induction over basal level of relative LUC activity for both constructs (K224, K638) was compared; results are shown in panel B. Bars indicate the mean ( $\pm \mathrm{SE}$ ) of fold induction of LUC activity over control nonmutated constructs $(=1)$, for a minimum of three independent experiments. C, Functional assays of double and triple deletion of the putative c/EBP binding sites on the KAP promoter. Functional activities of $1 \mu \mathrm{g}$ of $\mathrm{K} 638$ mutated constructs in two sites: K638 $(457-448,429-420)$ or in three sites: K638 (457-448, 429-420, 110-101) and K638 (457-448, 429-420, 66-56) were tested in PCT3 cells and compared with $1 \mu \mathrm{g}$ of $\mathrm{K} 638$ (wild type) following the same procedures as described in Fig. 5A. For each mutated construct, an additional situation, which corresponds to cotransfection of $0.5 \mu \mathrm{g}$ of pMSV-c/EBP $\alpha$ and PMSV-c/EBP $\beta$ expression vectors, was included. Bars indicate the mean of fold induction of LUC activity over control nonmutated constructs $(=1)$, for a minimum of three independent experiments. Error bars are not visible because values were too small to be depicted at this scale. D, Effects of steroid hormone depletion and/or ARE mutation on transcriptional activity of the K638 $(\Delta 457-448, \Delta 429-420)$ construct. The K638 $(\Delta 457-448, \Delta 429-420)$ construct was additionally deleted at the identified functional androgen receptor site (ARE) at position -39 from the transcription start site on the KAP promoter (15). The mutated ARE lacks the underlined sequence: $5^{\prime}$-GGTACAGGATGTATAAA-3' from positions -39 to -34 . Functional activities of $1 \mu \mathrm{g}$ of $\mathrm{K} 638$ mutated constructs $\mathrm{K} 638(\Delta 457-448, \Delta 429-420)$ and K638 ( $\Delta 457-448, \Delta 429-420, \Delta 39-34)$ were assayed in PCT3 cells and compared with $1 \mu \mathrm{g}$ of K638 (wild type), following the same procedure as described in Fig. 5A. The experiment was conducted in complete medium that includes presence of steroid hormones (left upper panel) or in steroid hormone-depleted media (right upper panel). For each mutated construct, an additional situation corresponding to cotransfection of $0.5 \mu \mathrm{g}$ of $\mathrm{pMSV}-\mathrm{c} / \mathrm{EBP} \alpha$ and PMSV-c/EBP $\beta$ expression vectors was included. As a control, $1 \mu \mathrm{g}$ of pGL3 basic vector was transfected or cotransfected with $0.5 \mu \mathrm{g}$ of pMSV-c/EBP $\alpha$ and PMSV-c/EBP $\beta$ expression vectors, in complete (left lower panel) or steroid-free media (right lower panel). Bars indicate the mean of fold induction of LUC activity over control nonmutated constructs $(=1)$, for a minimum of three independent experiments. Error bars are not visible because values were too small to be depicted at this scale. 
A

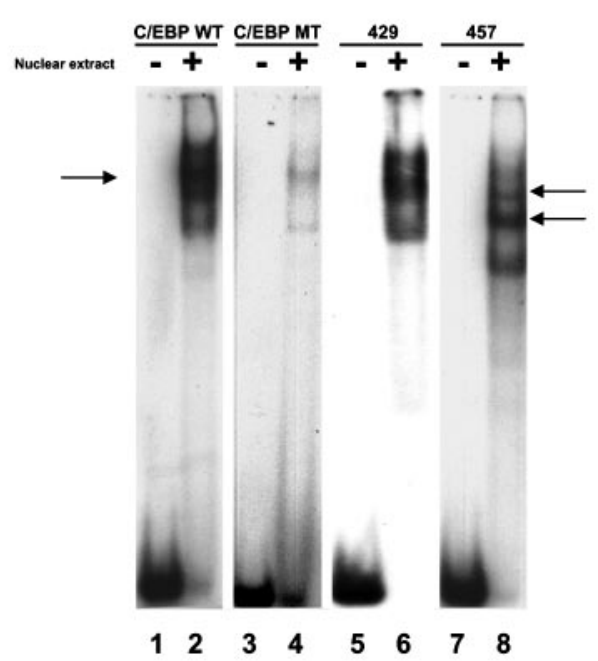

C

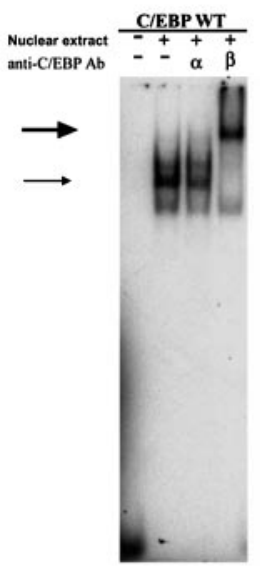

$\begin{array}{llll}1 & 2 & 3 & 4\end{array}$

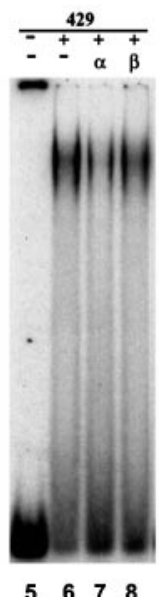

$\begin{array}{llll}5 & 6 & 7 & 8\end{array}$
B
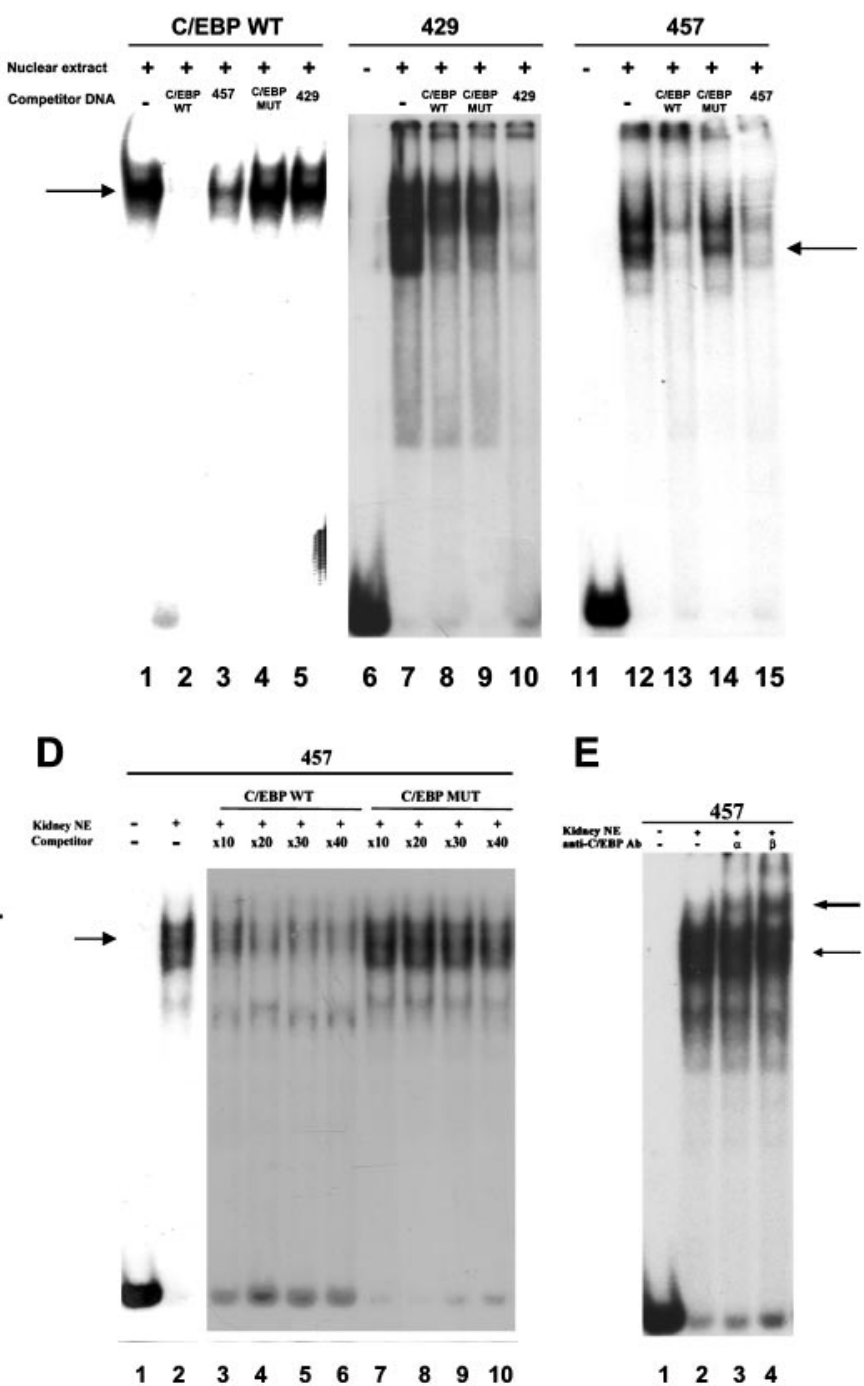

E

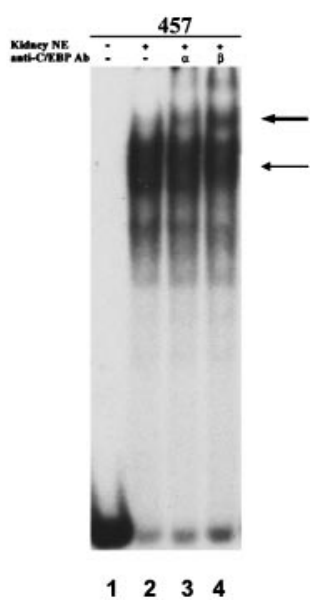

Fig. 6. Box 457 Binds c/EBP

A, EMSA of boxes 429 and 457. Five micrograms of nuclear extracts from PCT3 cells were incubated with ${ }^{32} \mathrm{P}$-labeled oligonucleotide duplex containing sequences corresponding to box 457 (lane 8) and box 429 (lane 6) from the KAP proximal promoter and analyzed by gel shift assay. ${ }^{32} \mathrm{P}$-labeled c/EBP consensus WT (lane 2) or c/EBP MUT sequences (lane 4), from Santa Cruz Biotechnologies, were used as positive and negative binding controls, respectively. Lanes 1, 3, 5, and 7 are controls for free DNA probe. The sequences for each probe are described in Materials and Methods. B, Competitive EMSA of boxes 429 and 457. Specific protein binding by ${ }^{32}$ P-labeled oligonucleotide duplex probes c/EBP WT (lanes 1-5), box 429 (lanes 7-10) and box 457 (lanes 12-15), incubated with $5 \mu \mathrm{g}$ of nuclear extracts from PCT3 cells, was competed with 30-fold molar excess of cold oligonucleotides, corresponding to c/EBP WT (lanes 2, 8, and 13), c/EBP MUT (lanes 4, 9, and 14), box 429 (lanes 5 and 10 ) and box 457 (lanes 3 and 15) sequences, described in Fig. 6A. Band patterns with no competitor oligonucleotide added are also shown in each case (lanes 1, 7, and 12). Lanes 6 and 11 are controls for free DNA probe. C, Supershift assays of complexes bound in boxes 429 and 457 . The composition of complexes formed in the 429 and 457 boxes (lanes 6 and 10) was further analyzed by the incorporation of anti-c/EBP $\alpha$ (lanes 7 and 11) and c/EBP $\beta$ (lanes 8 and 12) antibodies to the binding reaction and compared with the c/EBP WT sequence (lanes 2-4). The supershifted complexes (lanes 4 and 12) are indicated by a thick arrow and nonshifted complexes by a thin arrow. Lanes 1, 5, and 9 are controls for free DNA probe. D, Competitive EMSA of the 457 box using mouse kidney nuclear extracts. Specific protein binding by ${ }^{32} \mathrm{P}$-labeled oligonucleotide duplex probe 457, incubated with $25 \mu \mathrm{g}$ of nuclear extracts from adult male mouse kidney (lane 2), was competed with the indicated-fold molar excess of cold c/EBP WT (lanes 3-6) and c/EBP MUT (lanes 7-10) oligonucleotides. Lane 1 represents a control for free DNA probe. The position of the complexes is indicated by an arrow on the left. E, Supershift assays of complexes bound in box 457 with kidney extracts. The composition of complexes formed in the 457 box (lane 2) in the presence of mouse kidney extracts was further analyzed by the incorporation of anti-c/EBP $\alpha$ (lane 3) and c/EBP $\beta$ (lane 4) antibodies to the binding reaction. The supershifted complexes (lanes 3 and 4) are indicated by thick arrows on the right; a thin arrow marks the position of unshifted complexes. Lane 1 represents a control for free DNA probe. 
Because we already knew that the $\mathrm{KClO}_{4}$ treatment was effective to render the animals hypothyroid, and animals in this study presented the same dwarf phenotype as before, hormone levels were not measured.

Although both models apparently showed the same defect, homozygous mice for the recessive hyt mutation exhibited lower cortical expression than controls, whereas perchlorate-treated animals showed complete absence of KAP mRNA from the early stages of development (11). In addition, in potassium perchlorate-treated adult males, cortical expression did not disappear but only decreased (11). In light of these data, our first hypothesis to explain the differences between models was that exposure to maternal $\mathrm{TH}$, in obligated heterozygous hyt/+ mothers, was responsible for priming and enabling KAP cortical response in adult hyt/hyt males, whereas mice born of mothers exposed to goitrogen during gestation became unable to express KAP in adult life. Although the damage caused by lack of maternal and fetal TH in the developing brain had been reported (see Ref. 20 for review), the results of this work do not support the concept that prenatal TH deprivation is responsible for KAP expression prevention, but rather demonstrate that its postnatal presence makes expression possible.

Another distinctive feature between both hypothyroidism models was the significant growth failure associated with perchlorate treatment, which has also been described in childhood hypothyroidism (21). Hyt mice, previously used in our laboratory (8), present slightly lower weight than normal littermates, approximately $20 \mathrm{~g}$, whereas animals under postnatal perchlorate treatment are about half the weight, i.e. approximately $10 \mathrm{~g}$. TH involvement in the regulation of the rat $\mathrm{GH}$ promoter (22), its interaction with retinoic acid receptors (23) and the participation of cell-specific transcription factors such as Pit-1/GH factor-1 (24) to fully accomplish GH expression have been reported.

This observation prompted us to hypothesize that, although absence of TH diminishes KAP cortical expression, combined $\mathrm{TH}$ and $\mathrm{GH}$ deficiency abolishes it. In situ hybridization analysis performed in the $\mathrm{GH}$ deficient lit/lit mice (25) and Jackson dwarf mice, deficient in TSH, PRL, and $\mathrm{GH}$ due to an inactivating mutation in the anterior pituitary-specific transcription factor Pit-1 (26), revealed that $\mathrm{GH}$ and $\mathrm{TH}$ combined deficiency does compromise KAP gene expression in cortical segments in this genetically deficient mouse model. These results provided further evidence of the in vivo interactions between $\mathrm{GH}$ and $\mathrm{T}_{3}$ for the regulation of KAP gene and, also, that lack of KAP mRNA was not related to putative undesirable perchlorate side effects.

This concept was further challenged by administration of $\mathrm{T}_{3}, \mathrm{GH}$ or both hormones simultaneously to perchlorate-treated males on d 7-21. When mice were euthanized, on postnatal d 40, it became clear that $T_{3}$ replacement overcomes the inhibitory effects of perchlorate and that this effect is even more prominent in the presence of $\mathrm{GH}$. These results, together with our previous data (11), strongly support the idea that $\mathrm{TH}$ deprivation without consequences on severe growth retardation, i.e. in hyt mice and in adult perchloratetreated mice, reduces but does not abolish KAP expression, whereas absence of $\mathrm{TH}$ associated with severe growth retardation, i.e. Jackson/dwarf mice and mice treated postnatally with perchlorate results in absolute absence of KAP mRNA. Transient transfection assays from our laboratory had demonstrated that the KAP promoter enhances its response to androgens by 2.5-fold, in the presence of IGF-I (15). These data, together with the in vivo results presented in this work, support the concept that GH can modulate androgen-dependent KAP cortical expression in mouse kidney.

Although poorly studied in mice, the participation of $\mathrm{TH}$ and $\mathrm{GH}$ in gonadal development and puberal maturation has been described in rats (27-31). According to those studies, the lack of expression of sexual dimorphic kidney markers such as KAP could, in part, be related to insufficient androgen levels; nevertheless, our data indicate that other factors must be involved because discrete presence of $\mathrm{T}_{3}$ for $48 \mathrm{~h}$ anytime after postnatal d 10, promotes cortical expression of the gene, when analyzed at postnatal d 40. This time, which is too short to reprogram gonadal development in males, might be sufficient to induce one or more $\mathrm{T}_{3} / \mathrm{GH}$-dependent factors required to collaborate with androgens in KAP expression.

From the in vivo data presented here, we propose that postnatal expression of KAP mRNA in proximal convoluted tubules requires the presence of androgens and, also, the contribution of developmentally regulated factors triggered essentially by $T_{3}$. Taking into account the punctual need of $\mathrm{T}_{3}$, we also hypothesize that, after TH priming and in the presence of some androgen levels, the one or more factors involved in KAP expression must be either autoregulated or under the control of hormones or stimuli other than $\mathrm{T}_{3}$.

The transcription factors CCAAT/enhancer-binding proteins (c/EBPs) are members of the bZIP (basic region leucine zipper) class of DNA-binding proteins. They play an important role in cellular differentiation and development (32-36) and fulfill many of the requirements of the hypothesized factor(s) involved in the regulation of KAP expression in kidney cortex. Congenital hypothyroidism causes a significant decrease in expression of both c/EBP $\alpha$ and $\beta$ isoforms at early stages of postnatal liver development (17), and $\mathrm{T}_{3}$ positively regulates c/EBP $\alpha$ gene expression through a functional $\mathrm{TH}$ response element found in c/EBP $\alpha$ proximal promoter (37). c/EBP $\beta$ has also been reported to contribute to regulating $\mathrm{c}$-fos expression mediated by $\mathrm{GH}$ (38). It has recently been reported that $\mathrm{GH}$ promotes relocalization of $\mathrm{c} / \mathrm{EBP} \beta$ to heterochromatin, in association with the activation of MAPK signaling, introducing a new level of transcriptional regulation mediated by this hormone. GH-mediated 
phosphorylation and nuclear redistribution of c/EBP $\beta$ may be coordinated to achieve spatial-temporal control of gene expression (39).

Correlation of $\mathrm{c} / \mathrm{EBP} \alpha$ and $\beta$ levels in nuclear and cytoplasmic kidney extracts of perchlorate-treated males with KAP mRNA expression, in contralateral kidneys of the same animals, showed that, in the absence of both forms of c/EBP, there is no expression of KAP. Moreover, $\mathrm{T}_{3}$ injection in perchloratetreated males recovers levels of both c/EBPs and restores KAP expression. Direct evidence of c/EBPs involvement in KAP transactivation was obtained by performing transient transfection assays of the KAP proximal promoter (K638) fused to the CAT reporter gene in PCT3 cells. This promoter fragment (Fig. 4A) was selected for transfection because it contains four putative c/EBP binding sites at positions -66 , $-110,-429$, and -457 . Our results showed that transfection of c/EBP $\alpha$ or $\beta$ (Fig. 4B, lanes 7 and 9) exerts the same effect on transcriptional activity as transfection of the AR in the presence of DHT (Fig. 4B, lane 3) and also that simultaneous cotransfection of $\alpha$ and/or $b$ c/EBPs and AR, in the presence of androgens, (Fig. 4B, lanes 4-6) produces an additive effect on K638 transcriptional activity. Altogether, these results support the concept that the effects of $\mathrm{T}_{3}$ on the androgenic response of KAP observed in kidney are, at least in part, mediated by c/EBP $\alpha$ and $\beta$.

Site-directed mutagenesis was performed at specific sites to elucidate which of the putative c/EBP binding sites on the promoter were functionally significant (Fig. 5A). Results (Fig. 4B) indicated that mutation of individual sites had no effect on promoter activity, whereas simultaneous mutation of boxes -429 and -457 decreased the transcriptional activity of the promoter approximately 40 -fold (Fig. 4C), thereby indicating that these sites are functionally significant when they work in a cooperative fashion.

Deprivation of steroid hormones and/or mutation of the ARE at $39 \mathrm{bp}$ from the transcriptional initiation site was performed to further investigate whether factors binding to these functional sites could cooperate with the androgenic response. The 100- to 150 -fold decrease in promoter activity obtained in either situation clearly demonstrated a functional relationship between transcription factors bound to the -457 and -429 boxes and the AR.

Competitive shift and supershift assays performed to verify that the -457 and -429 sites were bindingspecific nuclear factors and identify their nature demonstrated that $\mathrm{c} / \mathrm{EBP} \alpha$ and $\beta$ bind to the -457 box but not to the -429 . The nature of the factor bound to box 429 remains to be identified. Overall, the data presented here, together with previous contributions from our laboratory indicate that expression of the KAP gene in epithelial cells of proximal convoluted tubules depends not only on androgens and functional androgen receptors, but also on transcription factors that bind at boxes -457 and -429 in the proximal pro- moter. c/EBP $\alpha$ and $\beta$ can bind to the -457 box, activate transcription and, together with a third party, bind to box -429 and trigger expression of the gene when androgen levels are sufficient in males. After birth, the presence of $\mathrm{TH}$ and $\mathrm{GH}$ is required for sexual maturity and expression of $\mathrm{c} / \mathrm{EBP} \alpha$ and $\beta$. Once these factors have been expressed and probably because they can be autoregulated $(40,41)$, TH becomes dispensable and cortical KAP expression occurs in the presence of androgens alone.

Study of the KAP gene has raised the theory that androgens are necessary, but not sufficient, to initiate an androgenic response in kidney and that other developmentally regulated factors, ultimately controlled by $T_{3}$, are involved. Studies with the ornithine decarboxylase (ODC) gene demonstrate that the lack of renal androgenic response during the postnatal period cannot be related only to the low levels of plasma testosterone at that time, but rather to immaturity of renal mechanisms to respond to androgens, which follow a maturational process in which testosterone could be only one of the factors implicated (42). Induction of renal ODC by androgens in adult mice requires activation of the transduction cascade mediated by catecholamines binding to $\alpha 1$-adrenergic receptors (43). Reports describe the existence of a critical period for $T_{3}$ to play a role in development of renal $\alpha 1$-adrenergic receptors (44); the influence of $\mathrm{TH}$ in the development of $\beta$ adrenergic control of ODC in rat kidney and heart (45) and evidence that $\mathrm{c} / \mathrm{EBP} \alpha$ is required for transcription of $\beta$-adrenergic receptors in adipose tissue (46) suggest that c/EBPs under $\mathrm{T}_{3}$ control might not only be involved in the androgenic control of KAP gene expression, but rather constitute a more general phenomenon for transcriptional control of androgen-regulated genes in kidney.

\section{MATERIALS AND METHODS}

\section{Materials}

Media for cell culture and LIPOFECTAMINE reagent were obtained from Life Technologies, Inc. (Gaithersburg, MD). Fetal calf serum, trypsin, glutamine, and essential amino acids were obtained from Biological Industries (Kibbutz Beit Haemek, Israel). Other supplements for cell culture, acetyl coenzyme A, steroid hormones, THs, and thin-layer chromatography plates were obtained from Sigma (St. Louis, MO). Human GH was a generous gift from Kabi-Pharmacia (Uppsala, Sweden). Restriction and modifying enzymes were purchased from either Life Technologies, Inc., Promega (Madison, WI), Amersham Pharmacia Biotech (Amersham, Buckinghamshire, UK), TaKara Shuzo Co. Ltd. (Shiga, Japan), or Roche Molecular Biochemicals (Mannheim, Germany). Oligonucleotides were synthesized by TIB MOLBIOLShyntheselabor (Berlin, Germany). All other reagents were obtained as previously reported $(6,8,11)$. 


\begin{abstract}
Animals
Jackson $d$ warf (strain $\mathrm{C}^{3} \mathrm{H} / \mathrm{HeJ}-d w^{j} / d w^{j}$ ), little mice (strain C57BL/6J-lit/lit) and their genetically matched normal controls (strain $\mathrm{C}^{3} \mathrm{H} / \mathrm{HeJ} d w^{j} /+$ and $\mathrm{C} 57 \mathrm{BL} / 6 \mathrm{~J}-$ lit/+) were obtained at 4-8 wk from The Jackson Laboratory. C57BL/6 control mice were obtained at 6 wk of age from Charles River España (Barcelona, Spain).

Mice were housed in the animal facilities in covered cages at $22 \mathrm{C}$ with $12 \mathrm{~h}$ light and darkness cycles. Pelleted food and tap water were supplied ad libitum.

At the time of the experiment, animals were euthanized by cervical dislocation. Kidneys were removed and snap-frozen immediately in liquid nitrogen in the presence of 2-methylbutane. All animal experimental procedures were conducted in accordance with Institutional standards which fulfill the requirements established by the Spanish Government and the European Community (Real Decreto 223/1988: B.O.E. no. 67, 3/18/88) and B.O.E. no. 256, 10/25/90).
\end{abstract}

\section{Hormone Treatment}

$\mathrm{T}_{3}$ hormone was resuspended in $10 \mathrm{mM} \mathrm{KOH}$ and $1.2 \mu \mathrm{g} /$ animal/d were administered sc human $\mathrm{GH}$ was reconstituted with $\mathrm{Na}_{2} \mathrm{CO}_{3} 25 \mathrm{~mm}(\mathrm{pH}$ 9.4) in $0.9 \% \mathrm{NaCl}$ and $18 \mu \mathrm{g} /$ animal/d were injected, sc. Pharmacologically induced congenital hypothyroidism was achieved through addition of $1 \%$ $\mathrm{KClO}_{4}$ to drinking water of pregnant dams at d 10 of gestation. From birth until being euthanized, animals were exposed to goitrogen, even when other treatments were simultaneously performed. The corresponding sham treatments were effected in all experimental situations. Hypothyroidism in newborn mice was induced using the same drugs at the same concentration until the animals were euthanized. When required, $\mathrm{KClO}_{4}$-treated water was replaced by normal tap water.

\section{Probe Synthesis and in Situ Hybridization Histochemistry}

${ }^{35} \mathrm{~S}$-Labeled transcripts from pKAP3 or pKAP4 cDNA plasmids, which correspond to antisense and sense cRNA, respectively, were prepared as previously described (14). The preparation of renal sections, hybridization protocol and autoradiographic analysis were all performed as reported (8, 11). Hybridized sections were examined under a light microscopy. Positive silver grain staining (appearing in black) determined the site of KAP mRNA synthesis (using KAP3 probe) in proximal tubule cells. All sections hybridized with the mRNA KAP4-specific strand sense probe exhibited no detectable silver grain staining (data not shown).

The magnification chosen for the images shown in the figures $(\times 40)$ permitted visualization of the three major compartments of the kidney (cortex, c; outer medulla, o; inner medulla, i) and determination of the spatial location of KAP mRNA. Kidney sections from same figure were each analyzed in a single experiment. Consequently, slides were exposed to the same conditions throughout the entire procedure, and KAP mRNA expression levels on different slides were comparable. Photomicrographs shown in the figures were selected from similar results obtained in different experiments using animals from different litters.

\section{RNA Extraction and Semiquantitative RT-PCR}

Total RNA was extracted from kidneys of animals using the guanidinium thiocyanate method (47). Different amounts of total RNA were used in each RT-PCR using the SuperScript One-Step RT-PCR System (Life Technologies, Inc.) under conditions previously reported. Primer sequences for KAP and CypA internal control genes have already been described (15).

\section{Preparation of Protein Extracts and Western Blotting}

Kidney tissues were homogenized in buffer A containing 20 $\mathrm{mm}$ Tris- $\mathrm{HCl}$ (pH 6.8), $50 \mathrm{~mm} \mathrm{NaCl}, 3 \mathrm{~mm} \mathrm{MgCl}, 300 \mathrm{~mm}$ sucrose; $1 \%$ Triton $\mathrm{X}-100,2 \mathrm{~mm}$ phenylmethanesulfonyl fluoride, $10 \mu \mathrm{g} / \mathrm{ml}$ aprotinin, $10 \mu \mathrm{g} / \mathrm{ml}$ leupeptin, and $1 \mathrm{~mm}$ $\mathrm{Na}_{3} \mathrm{OV}_{4}$. Homogenates were centrifuged for $15 \mathrm{~min}$ at 13,000 $\mathrm{rpm}$. Supernatant (cytosol and membrane fraction) was heated at $70 \mathrm{C}$ for $5 \mathrm{~min}$, centrifuged for $20 \mathrm{~min}$ at $14,000 \mathrm{rpm}$ and supernatant (cytosol) frozen at $-80 \mathrm{C}$. The pellet from the original kidney homogenates (including nuclear fraction) was resuspended in buffer $\mathrm{B}$ containing $25 \mathrm{~mm}$ Tris- $\mathrm{HCl}(\mathrm{pH}$ 7.5), $1 \mathrm{~mm}$ EGTA, $2 \mathrm{~mm}$ EDTA, 1\% SDS, and $2 \mathrm{~mm}$ phenylmethanesulfonyl fluoride, $10 \mu \mathrm{g} / \mathrm{ml}$ aprotinin, $10 \mu \mathrm{g} / \mathrm{ml}$ leupeptin, and $1 \mathrm{mM} \mathrm{Na}_{3} \mathrm{OV}_{4}$. The suspension was sonicated until clarified, centrifuged for $15 \mathrm{~min}$ at $13,000 \mathrm{rpm}$ and the supernatant (nuclear fraction) saved at $-80 \mathrm{C}$. All steps were performed at $4 \mathrm{C}$. Protein concentration was determined by the micromethod of Bio-Rad (Hercules, CA) using BSA as a standard.

Protein extraction from cell cultures was performed using the same protocol except that, after washing of plates with PBS, cells were scraped with a rubber policeman and homogenized with buffer $A$ on a rocking platform for $60 \mathrm{~min}$ at $4 \mathrm{C}$. The remaining procedures were the same as for kidney extracts.

Fifty micrograms of nuclear and cytosolic proteins from mouse kidney or cultured cells were size-fractionated by denaturing $12 \%$ SDS-PAGE. Proteins were electroblotted onto polyvinylidene difluoride membranes (Shleicher \& Schuell, Keene, NH) in transfer buffer (50 mM Tris- $\mathrm{HCl}, 40 \mathrm{~mm}$ glycine, $20 \%$ methanol) and blots blocked overnight at $4 \mathrm{C}$ in $4 \%$ BSA in TBST [Tris- $\mathrm{HCl} 20 \mathrm{~mm}(\mathrm{pH} 7.6), \mathrm{NaCl} 130 \mathrm{~mm}$ and Tween 20 at $0.1 \%$ ]. Primary polyclonal rabbit antibodies antic/EBP $\alpha(14 \mathrm{AA})$ and anti-c/EBP $\beta$ (C-19) from Santa Cruz Biotechnologies (Santa Cruz, CA) were diluted at $0.2 \mathrm{mg} / \mathrm{ml}$ in blocking buffer. Washes were performed following the membrane manufacturer's instructions and secondary antibody (horseradish peroxidase-conjugated goat antirabbit; Dako A/S, Glostrup, Denmark) was diluted 1:5000 and incubated for $1 \mathrm{~h}$ at room temperature. After washing, bands were detected using the ECL+ chemiluminescence detection method (Amersham Pharmacia Biotech) and exposed to Hyperfilm. To assess specificity of the antibodies, several assays were performed using specific blocking peptides (5-fold excess) (sc-61) for c/EBP $\alpha$, (sc-150 P) for c/EBP $\beta$ and nonspecific (sc-565P) for gp-130, from Santa Cruz Biotechnologies.

\section{Plasmid Constructs}

The strategy for obtaining the promoter fragments consisting of nucleotides (nt) -224 to +1 and -638 to +1 in the KAP gene (relative to the transcription start site) has already been described (15). Constructs were verified by extensive restriction mapping and partial DNA sequencing. All promoter lengths are available in both CAT and LUC promoterless vectors. The pCAT-Basic and pGL3-Basic vectors were obtained from Promega Corp. (Madison, WI).

The expression plasmid for $\beta$-galactosidase $\mathrm{pCH} 110$ (Amersham Pharmacia. Biotech) and the Renilla LUC reporter plasmid pRL-TK (Promega Corp.) were used to normalize transfection efficiencies of CAT and LUC assays, respectively. Plasmid pSVAR0 containing a simian virus 40 promoter that directs transcription of the full-length human androgen receptor cDNA was kindly provided by Dr. C. López-Otín (Universidad de Oviedo, Spain) (48). TH receptor, consisting 
of cDNA-encoding rat T3R $\alpha 1$ cloned in $\mathrm{pCDM} 8$, retinoid $\mathrm{X}$ receptor expression vector, human retinoid $X$ receptor $\alpha$ cDNA cloned in plasmid pSG-5 and the SaltK reporter construct, which corresponds to a TH-responsive element introduced into the reporter plasmid pBLCAT2 upstream of the heterologous Herpes simplex virus-thymidine kinase promoter, were kindly provided by Dr. A. Muñoz (Instituto de Investigaciones Biomédicas Alberto Sols, Centro Superior de Investigaciones Cientificas, Spain) (49). pMSV-c/EBP $\alpha$ and PMSV-c/EBP $\beta$ are expression vectors that contain the entire open reading frame of rat c/EBP $\alpha$ and c/EBP $\beta$ (p35 LAP), respectively, driven by the murine sarcoma virus promoter (50). They were kindly provided by Dr. M. Giralt (Universitat de Barcelona).

\section{Transient Transfection Studies}

The cloned PKSV-PCT, referred to as PCT3 cells, has previously been described (15). The culture conditions have also been reported $(12,13)$. Transient transfection experiments were performed as previously reported (15).

\section{CAT and LUC Assays}

These assays were performed as previously reported (15). Stimulation of CAT and LUC activities were expressed as fold increase over activities of noninduced transfected cells with the same reporter plasmids set to 1 and based on at least three independent experiments.

\section{Site-Directed Mutagenesis of Putative c/EBP Binding Sites}

K224 (110-101), K224 (66-56), K638 (457-448), K638 (429420), K638 (110-101), and K638 (66-56) contain deleted putative c/EBP binding sites of the KAP promoter. K224 and K638 were used as the DNA mutagenesis template to anneal with the mutagenic primers. Additional ARE mutation at position -39 was performed as described (15).

Mutant strands were synthesized with Pfu Turbo DNA polymerase and used to transform Epicurian Coli XL1-Blue Supercompetent cells using the QuikChange site-directed mutagenesis kit (Stratagene, La Jolla, Ca). Plasmid DNAs were isolated from the selection plates and mutants were identified by sequencing.

\section{EMSA Experiments}

Nuclear extracts from PCT3 cells were prepared as described by Dignam et al (51) without dialysis. Nuclear extracts from C57BL/6 mice kidney were prepared as described by Landschulz et al. (52) starting from $3.5 \mathrm{~g}$ of tissue and without dialysis. For EMSA experiments, the ${ }^{32} \mathrm{P}$-labeled DNA fragments (C/EBP WT: TGCAGATTGCGCAATCTGCAA, C/EBP MUT: TGCAGAGACTAGTCTCTGCAA, 429:CTTCACTGTTCTCCAGCAATCTGCCAGGAT,457:GATAGTTCTGCTTTTGCAATGAGCAGTTCT were incubated with $25 \mu \mathrm{g}$ of kidney nuclear protein or $5 \mu \mathrm{g}$ of cellular nuclear protein in a binding buffer [20 mm Tris-HCl (pH 7.4), 75 mM KCl, 0.5\% Nonidet $\mathrm{P}-40,10 \%$ glycerol, $1 \mathrm{~mm}$ DTT] in the presence of $100 \mathrm{ng}$ of poly(deoxyinosine-deoxycytosine) and $50 \mathrm{ng}$ of acetylated $\mathrm{BSA}$ for $30 \mathrm{~min}$ at $37 \mathrm{C}$ in a final volume of $20 \mu \mathrm{l}$. Oligonucleotide competition experiments were performed under the same conditions by previous mixing of all the reagents and increasing amounts of corresponding cold oligonucleotides before nuclear protein addition. Supershift assays were performed by incubating the complexes for a further $10 \mathrm{~min}$ more at $37 \mathrm{C}$ with anti-C/EBP $\alpha$ and anti-C/EBP $\beta$ before loading. The samples were electrophoresed on 5\% acrylamide $0.5 \times$ TBE gels, dried, and developed with intensifier screen at $-80 \mathrm{C}$.

\section{Acknowledgments}

We thank Drs. Carlos López-Otín (Universidad de Oviedo, Oviedo, Spain), Juan Bernal and Alberto Muñoz (Instituto de Investigaciones Biomédica, Alberto Sols, CSIC, Madrid, Spain), and Marta Giralt (Universitat de Barcelona, Barcelona, Spain) for providing us with several expression and control constructs, Dr. Joan Lopez-Hellin (CIBBIM, Institut Vall d'Hebron) for critical reading of the manuscript, and Christine O'Hara for English corrections.

Received June 10, 2005. Accepted September 1, 2005.

Address all correspondence and requests for reprints to: Anna Meseguer, Ph.D., Centre d'Investigacions en Bioquimica i Biologia Molecular (CIBBIM), Institut de Recerca Vall d'Hebron, Vall d'Hebron 119-129, 08035 Barcelona, Spain. E-mail: ameseguer@vhebron.net.

This work was supported by Grant BMC 2001-2578 from Ministerio de Ciencia y Tecnología y MARATO de TV3. 2000 (to A.M.). M.S. and N.T. are predoctoral recipient fellows (Formación personal investigador) from the Comissió Interdepartamental de Recerca i Innovació Tecnològica.

\section{REFERENCES}

1. Toole JJ, Hastie ND, Held WA 1979 An abundant androgen-regulated mRNA in the mouse kidney. Cell 17: $441-448$

2. El-Meanawy MA, Schelling JR, Pozuelo F, Churpek MM, Ficher EK, lyengar S, Sedor JR 2000 Use of serial analysis of gene expression to generate kidney expression libraries. Am J Physiol Renal Physiol 279:F383-F392

3. Virlon B, Cheval L, Buhler JM, Billon E, Doucer A, Elalouf JM 1999 Serial microanalysis of renal transcriptomes. Proc Natl Acad Sci USA 96:15286-15291

4. Takenaka M, Imai E, Kaneko T, Ito T, Moriyama T, Yamauchi A, Hori M, Kawamoto S, Okubo K 1998 Isolation of genes identified in mouse renal proximal tubule by comparing different gene expression profiles. Kidney Int 53: 562-572

5. Meseguer A, Catterall JF 1990 Cell-specific expression of kidney androgen-regulated protein messenger RNA is under multihormonal control. Mol Endocrinol 4:240-1248

6. Cebrián $C$, Aresté $C$, Nicolás A, Olivé P, Carceller A, Piulats J, Meseguer A 2001 Kidney androgen-regulated protein interacts with cyclophilin $B$ and reduces cyclosporine A-mediated toxicity in proximal tubule cells. J Biol Chem 276:29410-29419

7. Meseguer A, Catterall JF 1987 Mouse kidney androgenregulated protein messenger ribonucleic acid is expressed in the proximal convoluted tubules. Mol Endocrinol 1:535-541

8. Solé E, Calvo R, Obregón MJ, Meseguer A 1994 Thyroid hormone controls the cell-specific regulation of the kidney androgen-regulated protein gene in S3 mouse kidney cells. Endocrinology 135:2120-2129

9. Meseguer A, Catterall JF 1992 Effects of pituitary hormones on the cell-specific expression of the KAP gene. Mol Cell Endocrinol 89:153-162

10. Meseguer A, Watson CS, Catterall JF 1989 Nucleotide sequence of kidney androgen-regulated protein mRNA and its cell-specific expression in $\mathrm{Tfm} / \mathrm{Y}$ mice. Mol Endocrinol 3:962-967 
11. Solé E, Calvo R, Obregón MJ, Meseguer A 1996 Effects of thyroid hormone on the androgenic expression of KAP gene in mouse kidney. Mol Cell Endocrinol 119: 147-159

12. Cartier N, Lacave R, Vallet V, Hagege J, Hellio R, Robine S, Pringault E, Cluzeaud F, Briand P, Kahn A, Vandewalle A 1993 Establishment of proximal tubule cell lines by targeted oncogenesis in transgenic mice using the Lpyruvate kinase-SV40 ( $T$ ) antigen hybrid gene. J Cell Sci 104:695-704

13. Lacave R, Bens M, Cartier N, Vallet V, Robine S, Pringault E, Kahn A, Vandewalle A 1993 Functional characteristics of proximal tubule cells line derived from transgenic mice harbouring L-pyruvate kinase SV-40 (T) antigen hybrid gene. J Cell Sci 104:705-712

14. Ouar Z, Solé E, Bens M, Rafestin-Oblin ME, Meseguer A, Vandewalle A 1998 Pleiotropic effects of dihydrotestosterone in immortalized mouse proximal tubule cells. Kidney Int 53:59-66

15. Soler M, Tornavaca O, Solé E, Menoyo A, Hardy D, Catterall JF, Vandewalle A, Meseguer A 2002 Hormonespecific regulation of the kidney androgen-regulated gene promoter in cultured mouse renal proximal tubule cells. Biochem J 366:757-766

16. Niu E-M, Meseguer A, Catterall JF 1991 Genomic organization and DNA sequence of the mouse kidney androgen-regulated protein (KAP) gene. DNA Cell Biol 10: $41-48$

17. Menendez-Hurtado A, Vega-Nunez E, Santos A, PerezCastillo A 1997 Regulation by thyroid hormone and retinoic acid of the CCAAT/enhancer binding protein $\alpha$ and $\beta$ genes during liver development. Biochem Biophys Res Commun 234:605-610

18. Stein SA, Shanklin DR, Krulich L, Roth MG, Chubb CM, Adams PM 1989 Evaluation and characterization of the hyt/hyt hypothyroid mouse. II. Abnormalities of TSH and the thyroid gland. Neuroendocrinology 49:509-519

19. Wolff $\mathrm{J} 1998$ Perchlorate and the thyroid gland. Pharmacol Rev 50:89-105

20. Morreale de Escobar G, Obregon MJ, Escobar del Rey F 2004 Role of thyroid hormone during early brain development. Eur J Endocrinol 151(Suppl 3):U25-U37

21. Robson H, Siebler T, Shalet SM, Williams GR 2002 Interactions between GH, IGF-1, glucocorticoids, and thyroid hormones during skeletal growth. Pediatric Res 52: 137-147

22. Samuels HH, Aranda A, Casanova J, Copp RP, Flug F, Forman BM, Horowitz ZD, Janocko L, Park HY, Pascual A, Raaka BM, Sahnoun H, Stanley F, Yaffe BM, Yang $C-R, Y e$ Z 1988 Identification of the cis-acting elements and trans-acting factors that mediate cell-specific and thyroid hormone stimulation of growth hormone gene expression. Recent Prog Horm Res 44:53-114

23. Garcia-Villalba $\mathrm{P}, \mathrm{Au}$-Fliegner M, Samuels $\mathrm{HH}$, Aranda $\mathrm{A}$ 1993 Interaction of thyroid hormone and retinoic acid receptors on the regulation of the rat growth hormone gene promoter. Biochem Biophys Res Commun 191: 580-586

24. Palomino T, Barettino D, Aranda A 1998 Role of GHF-1 in the regulation of the rat growth hormone gene promoter by thyroid hormone and retinoic acid receptors. J Biol Chem 273:27541-27547

25. Frohman MA, Downs TR, Chomczynski P, Frohman LA 1989 Cloning and characterization of mouse growth hormone-releasing hormone (GRH) complementary DNA: increased GRH messenger RNA levels in the growth hormone-deficient lit/lit mouse. Mol Endocrinol 3: 1529-1536

26. Li S, Crenshaw 3rd EB, Rawson EJ, Simmons DM, Swanson LW, Rosenfeld MG 1990 Dwarf locus mutants lacking three pituitary cell types result from mutations in the POU-domain gene pit-1. Nature 347:528-533

27. Rao JN, Liang JY, Chakraborti P, Feng P 2003 Effect of thyroid hormone on the development and gene expres- sion of hormone receptors in rat testes in vivo. J Endocrinol Invest 26:435-443

28. Maran RR, Arunakaran J, Aruldhas MM 2000 T3 directly stimulates basal and modulates LH-induced testosterone and oestradiol production by rat Leydig cells in vitro. Endocr J 474:417-428

29. Manna PR, Tena-Sempere M, Huhtaniemi IT 1999 Molecular mechanisms of thyroid hormone-stimulated steroidogenesis in mouse leydig tumor cells. Involvement of the steroidogenic acute regulatory (StAR) protein. J Biol Chem 274:5909-5918

30. Panno ML, Sisci D, Salerno M, Lanzino M, Pezzi V, Morrone EG, Mauro L, Palmero S, Fugaza E, Ando S 1996 Thyroid hormone modulates androgen and oestrogen receptor content in the Sertoli cells of peripubertal rats. $J$ Endocrinol 148:43-50

31. Hull KL, Harvey S 2000 Growth hormone: a reproductive endocrine-paracrine regulator? Rev Reprod 5:175-182

32. Darlington GJ, Ross SE, MacDougald OA 1998 The role of C/EBP genes in adipocyte differentiation. J Biol Chem 273:30057-30060

33. Dile AM 1998 Roles of CCAAT/enhancer-binding proteins in regulation of liver regenerative growth. J Biol Chem 273:30843-3086

34. Scott LM, Civin Cl, Rorth P, Friedman AD 1992 A novel temporal expression pattern of three C/EBP family members in differentiating myelomonocytic cells. Blood 80: 1725-1735

35. Robinson GW, Johnson PF, Hennighausen L, Sterneck E 1998 The C/EBP $\beta$ transcription factor regulates epithelial cell proliferation and differentiation in the mammary gland. Genes Dev 12:1907-1916

36. Sterneck E, Tessarollo L, Johnson PF 1997 An essential role for $\mathrm{C} / \mathrm{EBP} \beta$ in female reproduction. Genes Dev 11 : 2153-2162

37. Menendez-Hurtado A, Santos A, Perez-Castillo A 2000 Characterization of the promoter region of the rat CCAAT/enhancer-binding protein $\alpha$ gene and regulation by thyroid hormone in rat immortalized brown adipocytes. Endocrinology 141:4164-4170

38. Liao J, Piwien-Pilipuk G, Ross SE, Hodge CL, Sealy L, MacDougald OA, Schwartz J 1999 CCAAT/enhancerbinding protein $\beta$ (C/EBP $\beta)$ and $\mathrm{C} / \mathrm{EBP} \delta$ contribute to growth hormone-regulated transcription of c-fos. J Biol Chem 274:31597-31604

39. Piwien-Pilipuk G, Galigniana MD, Schwartz J 2003 Subnuclear localization of C/EBP $\beta$ is regulated by growth hormone and dependent on MAPK. J Biol Chem 278: 35668-35677

40. Niehof M, Kubicka S, Zender L, Manns MP, Trautwein C 2001 Autoregulation enables different pathways to control CCAAT/enhancer binding protein $\beta$ (C/EBP $\beta)$ transcription. J Mol Biol 309:855-868

41. Timchenko N, Wilson DR, Taylor LR, Abdelsayed S, Wilde M, Sawadogo M, Darlington GJ 1995 Autoregulation of the human $\mathrm{C} / \mathrm{EBP} \alpha$ gene by stimulation of upstream stimulatory factor binding. Mol Cell Biol 15: 1192-1202

42. Sanchez-Capelo A, Tejada F, Ruzafa C, Cremades A, Penafiel R 1999 Postnatal exposure to androgens alters renal ornithine decarboxylase ontogeny and abolishes renal sexual dimorphism in mice. Biol Neonate 76:72-83

43. Cremades A, Tovar A, Penafiel R 1992 Catecholamines are required for testosterone induction of ornithine decarboxylase in the mouse kidney. Biochem Int 27:823-830

44. Tan JP, Seidler FJ, Schwinn DA, Page SO, Slotkin TA 1997 A critical period for the role of thyroid hormone in development of renal $\alpha$-adrenergic receptors. Pediatr Res 42:93-102

45. Pracyk JB, Lappi SE, Slotkin TA 1991 Role of thyroid hormone in the development of $\beta$ adrenergic control of ornithine decarboxylase in rat heart and kidney. J Pharmacol Exp Ther 256:757-766 
46. Dixon TM, Daniel KW, Farmer SR, Collins S 2001 CCAAT/enhancer-binding protein $\alpha$ is required for transcription of the $\beta 3$-adrenergic receptor gene during adipogenesis. J Biol Chem 276:722-728

47. Chomczynski $P$, Sacchi N 1987 Single-step method of RNA isolation by acid guanidinium thiocyanate-phenolchloroform extraction. Anal Biochem 162:156-159

48. Balbin M, Lopez-Otin C 1996 Hormonal regulation of the human pepsinogen $\mathrm{C}$ gene in breast cancer cells. Identification of a cis-acting element mediating its induction by androgens, glucocorticoids, and progesterone. J Biol Chem 271:15175-15181

49. Sap J, Muñoz A, Schmitt J, Stunnenberg H, Vennstrom B 1989 Repression of transcription mediated at a thyroid hormone response element by the $\mathrm{v}$-erb-A oncogene product. Nature 340:242-244

50. Manchado C, Yubero P, Vinas O, Iglesias R, Villarroya F, Mampel T, Giralt M 1994 CCAAT/enhancer-binding proteins $\alpha$ and $\beta$ in brown adipose tissue: evidence for a tissue-specific pattern of expression during development. Biochem J 302:695-700

51. Dignam JD, Lebovitz RM and Roeder RG 1983 Accurate transcription initiation by RNA polymerase II in a soluble extract from isolated mammalian nuclei. Nucleic Acids Res 11:1475-1489

52. Landschulz WH, Johnson PF, Adashi EY, Graves BJ, McKnight SL 1988 Isolation of a recombinant copy of the gene encoding C/EBP. Genes Dev 2:786-800

Molecular Endocrinology is published monthly by The Endocrine Society (http://www.endo-society.org), the foremost professional society serving the endocrine community. 